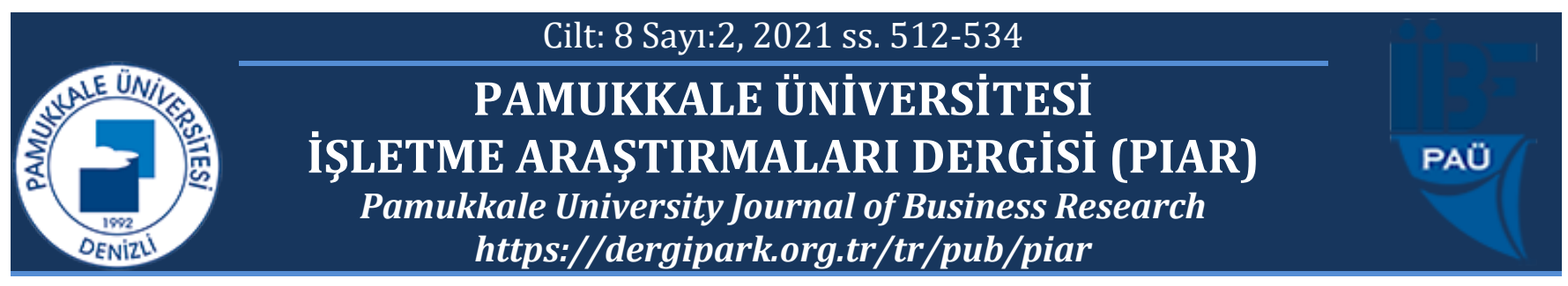

\title{
Sağlık Sistemlerinde Kamu-Özel Ortaklığı Uygulamaları Üzerine Bir İçerik
}

\section{Analizi}

\section{A Content Analysis on Public-Private Partnership Practices in Health Systems}

\section{S1ddıka ÇAM ${ }^{1 *} \quad$ Erdal EKE ${ }^{2}$}

\footnotetext{
1 Süleyman Demirel Üniversitesi, Sosyal Bilimler Enstitüsü, siddikacam032@gmail.com, https://orcid.org/0000-00020200-3526

2 Süleyman Demirel Üniversitesi, İktisadi ve İdari Bilimler Fakültesi, erdaleke@sdu.edu.tr, https://orcid.org/0000-00029529-5889

* Yazışılan Yazar/Corresponding author
}

Makale Geliş/Received: 12.10.2021

\section{Öz}

Siyasal ve ekonomik politikalarn dönüşümüyle birlikte 1980'lerden itibaren kamu-özel ortaklı̆̆̆, birçok ülkenin kamu hizmeti sunumunda bir model olarak kullanılmasıyla bilimsel çalışmalara konu olmaya başlamıştır. Bu çalışma, să̆lık sistemi içerisinde uygulanmaya başlayan bu yöntemin kullanımı ile ilgili yayınlanmış olan çalışmaları içerik açısından analiz etmeyi amaçlamaktadır. Bu amaçla, nitel araştırma temel veri analiz tekniklerinden birisi olan içerik analizi ile içerik analizinin alt tekniklerinden olan sıklık, kategori ve değerlendirici analiz teknikleri kullanularak 20102020 yılları arasında yayınlanmış nicel, nitel veya karma yöntemle gerçekleştirilmiş, 35 araştırma makalesi ve tez incelenmiştir. Araştırma sonunda bulgular dört temaya ayrılmıştır. Bunlar paydaşlar, memnuniyet, tutum ve deneyimler (hasta, çalışan, yönetici), kamu özel ortaklığının olumlu/olumsuz ve başarılı/başarısız yönleri ve diğerdir. Analiz neticesinde çalışmaların son yıllarda yoğunlaşmaya başladı̆̆ı, bu çalışmalarda ă̆ırlıklı olarak nitel yöntem kullanıldığ farklı alan ve sektörlerde kullanılmasının önerildiği tespit edilmiştir.

Anahtar kelimeler: Kamu-özel ortaklığıl, sağllk sistemi, sağlik yönetimi.

JEL kodlari: H10, H19, I10, I18
Makale Kabul/Accepted: 9.12.2021

\begin{abstract}
With the transformation of political and economic policies, public-private partnership has started to be the subject of scientific studies since the 1980s, with the use of many countries as a model in public service delivery. This study aims to analyze the published studies on the use of this method, which has started to be implemented in the health system, in terms of content. For this purpose, qualitative research was conducted using content analysis, which is one of the basic data analysis techniques, and frequency, category, and evaluative analysis techniques, which is one of the sub-techniques of content analysis, using quantitative, qualitative, or mixed methods published between 2010-2020, 35 research articles and theses were examined. At the end of the research, the findings were divided into four themes. These are stakeholders, satisfaction, attitudes and experiences (patient, employee, manager), positive/negative and successful/unsuccessful aspects of public-private partnership, and others. As a result of the analysis, it has been determined that the studies have started to intensify in recent years, that the qualitative method is mainly used in these studies and that this model is recommended to be used in different fields and sectors with a rate of $56 \%$.
\end{abstract}

Keywords: The public-private partnership, health system, health management.

JEL codes: H10, H19, I10, I18 


\section{GİRIŞ}

20. yüzyılın sonlarına kadar kamu hizmetleri ağırlıklı olarak devlet eliyle sunulmuş ve özel sektörün yeri çok kısıtlı olmuştur. Devlet tarafından sunulan kamu hizmetlerinin verimsiz, hantal, düşük kaliteli olması gibi eleştirilerin söz konusu olması ve 1970'li yıllarda iki petrol krizinin yaşanmasıyla da devletler ciddi mali zorluklarla yüz yüze gelmişlerdir (Kurun, 2017: 86). Bu durum, refah devlet anlayışını tartışılmalı bir konuma getirmiş ve Yeni Kamu Yönetimi anlayışının doğmasına sebep olmuştur. Yeni Kamu Yönetimi anlayışı, 1980'li yılların başında İngiltere'de Thatcher'le ve Amerika' da Reagan ile başlamış ve Avustralya, Kanada gibi gelişmiş; Güney Kore, Singapur gibi gelişmekte olan ülkelerde ve de Dünya Bankası, Uluslararası Para Fonu gibi uluslararası kuruluşların devletlere verdikleri kredilerle bu anlayış tüm dünyada benimsenmeye başlanmıştır (Boztepe, 2018: 192).

Kamu özel ortaklığı uygulamalarının tarihsel olarak çok eskilere dayandığına dair çalışmalar yer almaktadır. M. Ö. (Milattan Önce) 1200 yılında Mısır devleti ile paralı askerler arasındaki anlaşma ile M. Ö. 600'de Yunanistan şehir devletleri ile sözleşmeli özel tıp hekimleri arasında anlaşma yapılması ve de M. S. (Milattan Sonra) ise 1290 yılında Southampton'da suyun temini için kamu özel ortaklığı modeli kullanılmıştır (Minnie, 2011: 26). İngiltere' de 1660 yıllarında yol inşaatları, Fransa' da ise 1782 yılında içme suyunun temini için özel sektör ile iş birlikleri gerçekleştirilmiştir. Kamu özel ortaklığı uygulamalarının en bilineni ise 1869 yılında tamamlanan "Süveyş Kanalı" projesidir (Çekirge, 2006: 5). 1980 yılı itibariyle de geleneksel kamu yönetiminden vazgeçilerek, özelleştirmelerden sonra en çok kullanılan kamu özel ortaklığ1 modeli yaygınlık kazanmaya başlamıştır (Uğur ve Miynat, 2014: 19).

Devletin kamu hizmetlerini tek başına sunmasının verimsizliğe yol açtığ1 iddia edilirken; bu hizmetlerin serbest piyasa koşullarında sunulması halinde ise halk tarafından özelleştirme algısı oluşturma olasılığı sebebiyle alternatif bir yönteme gereksinim duyulmuştur (Ayhan ve Önder, 2018: 110). Bu alternatifin ise yapilan tartışma ve öneriler doğrultusunda kamu özel ortaklığı olduğu söylenebilir. Kamu hizmetlerinin özel sektör kişilerine yaptırılması 17. yüzyıla dayansa da (Boz, 2013: 280), kamu özel ortaklığı modeliyle iş yapma biçiminin 1980'lerden sonra popülerlik kazanmaya başladığı belirtilmektedir (Şenel Tekin, 2017: 7).

Kamu özel ortaklığı; ulaşım, enerji, su ve atık su, havalimanı gibi birçok alanda uygulanabilir olması sebebiyle yaygın bir kullanıma sahiptir. Dünya Bankası verilerine göre, 1990'lı yıllardan itibaren kamu özel ortaklığı uygulamaları gerçekleştirilmeye başlanmış; 2008 ekonomik kriz sonrasında yükselerek devam etmiş ve 2012 yılında 616 proje sayısı ile zirveye ulaşmıştır. Kamu özel ortaklığının; Doğu Asya ve Pasifik, Avrupa ve Merkez Asya, Latin Amerika ve Karayipler, Orta Doğu ve Kuzey Afrika, Güney Asya ve son olarak Sahra-altı Afrika bölgesinde en çok elektrik alanında uygulama alanı bulduğu görülmüştür (Dünya Bankası, 2021a). Sağlık hizmeti taleplerinin gün geçtikçe artması, sağlık harcamalarının yükselmesi, devletlerin tek başına sağlık sistemini finanse edememesi özel sektör ile işbirliği yapmasına yol açmış ve kamu özel ortaklığı yeni bir uygulama alanı olarak tercih edilmeye başlanmıştır.

Araştırma konusunun temeli, sağlık sistemlerindeki kamu özel ortaklığı uygulamaları olarak belirlenmiştir. Çalışmada öncelikle, sağlık alanındaki uygulamaları sürekli artan kamu özel ortaklığı modeli hakkında kısa bir alan yazınından sonra metodoloji 
kısmına geçilmiş ve araştırmanın amacı, yöntemi, kapsamı ve veri analizinden bahsedilmiştir. Bir sonraki başlıkta ise nitel araştırma temel veri analizlerinden olan içerik analizi ile 2010-2020 yılları arasında yayınlamış çalışmaların yayınlandı ğı yıllar, amaçları, yöntemleri, bulguları ve önerileri incelenmiş ve son olarak genel bir değerlendirme yapılmıştır.

\section{SAĞLIK SİSTEMLERINDE KAMU ÖZEL ORTAKLIĞI MODELİ: KAVRAMSAL ÇERÇEVE}

1990'l y yllar itibariyle kamu hizmetinin sunumunda finansman, inşaat, bakım-onarım ve işletme gibi çeşitli tür ve seviyelerde özel sektörün yer alması ile alan yazınında Public Private Partnerships (PPPs) olarak adlandırılan yeni bir finansman ve hizmet modeli ortaya çıkmıştır (Usta ve Bilgiç, 2016: 253). Türkçe literatürde Kamu Özel İşbirliği, Kamu Özel Sektör İşbirliği, Kamu Özel Ortaklığı ve benzeri başlıklarda kullanımına rastlamak mümkündür. Kamu özel ortaklığı coğrafi, demografik, ekonomik faktörlerden etkilendiği için evrensel kabul gören bir tanımı bulunmamaktadır. Avrupa Komisyonu tarafından yayınlanan Yeşil Kitap'ta kamu özel işbirliği "bir altyapının maddi olarak desteklenmesi, yapılması, yenilenmesi, yönetilmesi ve sürdürülmesi ya da bir hizmetin temin edilmesi için kamu sektörü ile özel sektör arasinda yapılan işbirliği biçimleri" (Commission of The European Communities, 2004: 3) olarak tanımlanmıştır. Dünya Bankası'nın yayınladığı PPP Referans Kılavuzu'nda (2017: 5) ise, "özel tarafin önemli risk ve yönetim sorumluluğu taşıdığı ve ücretin performansla bağlantılı olduğu bir kamu varlı̆̆ı veya hizmeti sağlamak için özel sektör ve devlet arasinda, uzun vadeli bir sözleşme" şeklinde yer almaktadır. Kamu özel ortaklı̆̆ı, bir kamu hizmetinin gerçekleştirilmesi için devletin, özel sektörle veya sivil toplum kuruluşlarıyla birlikte uzun vadeli sözleşmeler ile maliyet, risk ve faydanın taraflarca paylaşılmasını sağlayan bir modeldir (Kerman vd., 2012: 4; Öncü, 2018: 16). Kamu özel ortaklığının çeşitli özellikleri bulunmaktadır. Bu özellikler genel olarak şu şekildedir (EPEC, 2021a):

- Kamu sektörü ile özel sektör arasındaki işbirliği mal varlığından ziyade hizmetin sunulması için yapılan uzun vadeli sözleşmeleri kapsar.

- Kamu özel işbirliği ile projenin dizaynı, inşası, işletilmesi, bakım-onarımı ve/veya finansman riskleri özel ortağa transfer edilir.

- Kamu sektörü, hizmeti sağladığı için özel sektöre performansa dayalı ödeme veya gelir elde etme hakkı tanır.

Neoliberal politikalar, kamu hizmetlerinde esnek ve piyasa tabanlı olarak bir dönüşüm yaratmıştır (Kerman vd., 2012: 2). Bu dönüşüm ile birlikte devletler küçülmeye başlamış ve kamu hizmetlerinde artan yatırım ve finansman ihtiyacından dolay bu hizmetlerin işletmesini özel sektöre devretme gereği duyulmuştur (Gökkaya, 2020: 79). İngiltere kökenli yeni finansman türü olan kamu özel ortaklıkları, 90'lı yılların başında "kürek çeken değil, dümen tutan devlet" anlayışı, 1992 yılında İngiltere'de Mayor tarafından gerçekleştirilen "Özel Finansman Girişimi" ve Blair döneminde ise "En İyi Değer" uygulamaları bu modele örnek teşkil etmektedir (Çelik, 2008: 28).

Kamu özel ortaklığı yöntemi için çeşitli alt türler geliştirilmiştir. Bu alt türler birbirinden çok az farkla ayrılması sayesinde projenin yapısı, uygulanacağı alan, ekonomik ve coğrafi etkenlere göre kamu özel ortaklığı modelini tercih etmede 
esneklik kazandırmaktadır (Yereli ve Kızıltan, 2011: 248-250). Alt modellerden bazıları aşağıdaki gibidir (Bazı Yatırım Ve Hizmetlerin Kamu Kesimi İle Özel Sektör İşbirliği Modelleri Çerçevesinde Gerçekleştirilmesine İlişkin Kanun Tasarısı Taslağı, 2007: 3):

- Yap-İşlet (Yİ): Kamu ve özel sektör arasında imzalanan sözleşme neticesinde kamu hizmetinin sunulması için özel sektörün yapıyı finanse etmesi, gerektiğinde tasarlanması, inşası, bakım-onarımını, işletmesini üstlenir ve sözleşmenin sona ermesiyle mülkiyetin özel sektörde kaldığı bir kamu özel ortaklığı modelidir.

- Yap-İşlet-Devret (YİD): Kamu ve özel sektör arasında imzalanan sözleşme kapsamında kamu hizmetinin sunulması için özel sektörün yapıyı finanse etmesi, gerektiğinde tasarlaması, inşası, bakım-onarımını, işletmesini ve yönetimini en fazla 49 yıl üstlendikten sonra kamuya devredildiği bir modeldir.

- Yap-Kirala-Devret (YKD): Kamu ile özel sektör imzalanan sözleşme çerçevesinde özel tarafın finansı ile inşa edilen ve belirli bir süre için kira karşılığında yönetip, hizmetlerin kısmen ya da tümünü sunduktan sonra sözleşmenin sonunda mülkiyetin kamuya devredilmesidir.

- İşletme Hakkı Devri (İHD): Kamu idarelerinin aktiflerinde yer alan mal veya hizmetlerin, mülkiyetinin kamuda saklı kalmak koşulu ile bedelinin ödenerek belirli bir süre ve koşul altında işletme hakkının özel sektöre verildiği bir kamu özel ortaklığı modelidir.

Kamu özel ortaklığı modeli birçok avantaj ve dezavantaja sahiptir. KÖO'nun avantajları; kamu hizmetlerinin daha kaliteli ve hesaplı sunulması, altyapı yatırımlarının kamuda yarattığ finansman sorununu gidererek varlığın/hizmetin kısa sürede temin edilmesi, özel sektörün uzmanlığından yararlanarak sermayenin harekete geçirilmesi şeklinde siralanabilmektedir (Acartürk ve Keskin, 2012: 35). KÖO'nun dezavantajları incelendiğinde ise; değişen teknolojiye, koşullara ve taleplere uyum sağlamada uzun süreli sözleşmelerin yetersiz kalma durumu, özel sektöre devredilen risklerin doğru yönetilememesi (Sonğur, 2016: 54-55), ticari ilişkilerin belirsiz olması, sözleşmelerin karmaşık, muğlak olması ve eksiklikler barındırması, kamu sektörü yeterince bilgi ve deneyime sahip olmadığı için danışmanlık hizmeti alması ve maliyetlerde artış yaşanması şeklinde sıralanabilmektedir (Şenel Tekin, 2010: 20; Karahanoğulları, 2012: 122).

Kamu özel ortaklığı ile yapılan proje sayılarına uluslararası kuruluşlardan biri olan Dünya Bankası'ndan erişmek mümkündür. Bu bağlamda, 2019 yılı itibariyle Çin'de kamu özel ortaklığı projeleri ağırlıklı olarak yol alanında ve toplamda 1.904; Brezilya, elektrik sektörü projeleri ile öne çıkmakta ve toplam proje sayısı 1.051 ve Hindistan da elektrik olmakla birlikte 1.115 kamu özel ortaklığı projesi bulunmaktadır (Dünya Bankası, 2021b; Dünya Bankası, 2021c; Dünya Bankası, 2021d). Kamu özel ortaklı̆̆1 yönteminin dünyadaki uygulamalarına bakıldığında; Avusturya'da üç hastanenin sterilizasyon ünitesini yenilemek için yeterli kaynağa sahip olmayan kamu sektörü, kamu özel ortaklığı modeli ile yeni bir binanın inşa edilmesiyle maliyetlerde düşüş ve verimlilikte artış yaşanmıştır. Danimarka'da kamu yetkilileri ile IBM ve MedCom'un da olduğu konsorsiyum sayesinde ulusal e-sağlık portalı geliştirilmiştir; birçok işlem elektronik ortamda transfer edilmesiyle birlikte maliyetlerde azalma gerçekleşmiştir (Nikolic ve Maikisch, 2006: 16). Birleşik Krallık'ta 2015 yılında NHS Trust ve Carillion 
şirketi arasında yapılan anlaşma ile eski iki tesisin yerini alacak olan Midland Metropolitan Hospital PPP'nin finansal kapanışı gerçekleştirilmiştir (EPEC, 2021b). 2011 yılında İspanya hükümeti, Vigo şehrine kamu özel ortaklığı modeli ile 375 milyon Euro maliyetli Hospital de Vigo PPP adında yeni hastaneyi inşa etmiş ve bu hastane Vigo Üniversitesi hastanesi ile entegre bir şekilde hizmet vermektedir (EPEC, 2021c). Türkiye'de Yap-Kirala-Devret (YKD) alt modeli ile 18 şehir hastanesi projesi bulunmakta ve 13 hastane sağlık hizmeti sunmaya başlamıştır (T. C. Sağlık Bakanlığı, 2021).

\section{ARAŞTIRMANIN YÖNTEMI}

\subsection{Araştırmanın Amacı}

Siyasal ve ekonomik politikalardaki dönüşümle birlikte 1980'lerden itibaren kullanımı gittikçe artan kamu özel ortaklıkları, devletlerin finansman konusunda yaşadıkları sorunlara alternatif çözüm olarak görülmektedir. Gelişmiş ve gelişmekte olan ülkeler tarafından ulaşım, enerji, sanayi, eğitim ve sağlık gibi birçok alanda bu modele başvurulmaktadır. Bu çalışmada, farklı ülkelerin sağlık sistemlerinde uygulama alanı bulan kamu özel ortaklığı modelinin detaylı bir şekilde incelenmesi amaçlanmaktadır. Bu amaçla, 2010-2020 yılları arasında yayınlanan sağlık sistemlerindeki kamu özel ortaklığı uygulamalarını konu alan makale ve tez çalışmalarının yıl, amaç, yöntem, bulgu ve önerilerini içerik analizi yöntemiyle irdelenmeye çalışılmıştır.

\subsection{Araştırmanın Yöntemi}

$\mathrm{Bu}$ çalışmada ulaşılan verileri anlamlı bir şekilde bir araya getirecek kavram ve ilişkileri elde edebilmek için nitel araştırma temel veri analiz tekniklerinden birisi olan içerik analizinden yararlanılmıştır. İçerik analizinin tekniklerine bakıldığında; sıklık (frekans) analizi, kategori analizi, değerlendirici analiz, ilişki analizi ve diğer olmak üzere beş ana başlıkta toplandığı görülmektedir. Çalışma kapsamında sıklık (frekans) analizinin birimleri sayı, yüzde ve oranların sıklığını ifade etmesi; kategori analizi ile kodların belirli kriterler çerçevesinde sınıflandırılması ve değerlendirici analiz ile de konuya ilişkin tutumların avantaj ve dezavantajlarının belirlenmesinde kullanılması (Bilgin, 2006: 18-28) sebebiyle bu üç içerik analizi tekniğinden faydalanılmıştır.

\subsection{Araştırmanın Kapsamı}

Çalışmada, belirlenen anahtar kelimeler ile 2010-2020 yılları arasında yayınlanan makale ve tezler incelenmiştir. Amaçlı örneklem kapsamında ölçüt örneklem seçimi kullanılmıştır. Tarama kriterleri ve sonuçlarına ilişkin bilgiler ise Tablo 1'de yer verilmiştir.

Tablo 1. Tarama Kriterleri ve Sonuçları

\begin{tabular}{|l|l|}
\hline \multicolumn{1}{|c|}{ Tarama Kriterleri ve Sonuçları } \\
\hline DergiPark \\
Google Scholar ve Akademik \\
Scri Tabanları & Scopus \\
& Web of Science \\
YÖK Tez Merkezi
\end{tabular}




\begin{tabular}{|c|c|c|}
\hline Anahtar Kelimeler & $\begin{array}{l}\text { Sağlik } \\
\text { Sistemi } \\
\text { (Health } \\
\text { System) }\end{array}$ & $\begin{array}{ll}\text { - } & \text { Kamu-Özel Ortaklığı (Public-Private Partnerships) } \\
\text { - } & \text { Entegre Sağlık Kampüsü (Integrated Health Campus) } \\
\text { - } & \text { Sağlık Kampüsü (Health Campus) } \\
\text { - } & \text { Şehir Hastanesi (City Hospital) }\end{array}$ \\
\hline Arama Kriterleri & \multicolumn{2}{|c|}{$\begin{array}{l}\text { - Çalışmaların araştırma sürecinde veri toplamak için makale ve tezlerin } \\
\text { çalışma kapsamında incelemesi, } \\
\text { - } \quad \text { Doğrudan sağlık sistemlerinde kamu özel ortaklığı uygulamalarına } \\
\text { ilişkin çalışmalar olması, } \\
\text { - Çalışmalarda, nicel, nitel ya da karma yöntemlerinin kullanılmış olması, } \\
\text { - } \quad \text { Çalışmaların, 2010-2020 yılları arasında yayımlanmış olması, } \\
\text { - Çalışmaların, İngilizce ve Türkçe dilinde yazılmış olması, } \\
\text { - Çalışmanın tam metnine ulaşılmış olması. }\end{array}$} \\
\hline $\begin{array}{l}\text { Tarama Sonrasında Çıkan } \\
\text { Toplam Makale ve Tez Sayısı }\end{array}$ & \multicolumn{2}{|l|}{203} \\
\hline $\begin{array}{l}\text { Değerlendirilen Çalışma } \\
\text { Sayısı }\end{array}$ & \multicolumn{2}{|c|}{29 Makale ve 6 Tez } \\
\hline
\end{tabular}

Tablo 1'de yer alan anahtar kelimelerin makale ve tezlerin başlığında, özetinde ya da anahtar kelimeler kısmında yer alması koşulu ile tarama yapılmıştır. Tarama sonucunda 203 çalışmaya ulaşılmış ve belirlenen arama kriterlerine göre 29 makale ve 6 tez olmak üzere toplamda 35 çalışma araştırmaya dâhil edilmiştir.

Çalışmada, belirli anahtar kelimelerle içerik taraması yapılmış olup çevrimiçi dergilerdeki araştırma makaleleri ve tezler içerik analizi ile incelemeye tabi tutulmuştur. Literatür derlemesi ile yapılmış makale ve tezler ile kongre bildirileri araştırma kapsamına dâhil edilmemiştir. Konuya dair güncel bilgileri irdelemek adına 2010-2020 yılları arasında yayınlanmış ve yukarıdaki arama kriterleri çerçevesinde nicel, nitel veya karma yöntemle gerçekleştirilmiş çalışmaları kapsaması bu çalışmanın sinırlılıklarını oluşturmaktadır.

\subsection{Verilerin Analizi}

Çalışma kapsamında belirlenen kriterler içerik analiziyle incelenmiştir. İçerik analizinde "toplanan verilerin kavramsallaştırılması, daha sonra da ortaya çıkan kavramlara göre mantıklı bir biçimde düzenlenmesi ve buna göre veriyi açılayan temaların saptanması gerekmektedir" (Yıldırım ve Şimşek, 2016: 242). Bir başka tanıma göre ise içerik analizi, belirli kriterler çerçevesinde bir araya getirilen çalışmaların tümevarıma dayalı olarak, araştırmacının objektif şekilde ikinci bir okuma ile çıkarım ve yorum yapmasını sağlar (Bilgin, 2014: 1). Analiz neticesinde elde edilen bulgular tablo, grafik ve şekil haline getirilmiş, yorumlama kısmında frekans ve yüzde analizlerinden yararlanılmıştır.

\section{ARAŞTIRMANIN BULGULARI}

Bu bölümde Türkçe ve İngilizce yayınlanmış olan sağlık sistemlerinde kamu özel ortaklığı uygulamaları odaklı araştırmalara ilişkin bulgular aşağıdaki kategori kapsamında incelenmiştir:

- Araştırmaların yayınlandı̆̆ı yıl 


\section{- Araştırmaların amacı}

- Araştırmaların yöntemi

- Araştırmaların bulguları

- Araştırmaların önerileri

Çalışmada yukarıdaki başlıkların dışında kalan araştırmanın anahtar kelimeleri, sayfa sayısı, örneklem türü ve sayısı gibi alt başlıklara ilişkin değerlendirmeler bibliyometrik analize daha uygun olması bakımından içerik analizinin kapsamı dışına bırakılmıştır.

Tablo 1'de yer alan anahtar kelimeler kullanılarak arama kriterleri kapsaminda kamu özel ortaklığı ile ilgili araştırmalarını gerçekleştiren yazar(lara) ilişkin künye bilgisi ve hangi ülkede çalıştıkları ile çalışmanın yılı, türü, başlığı, nerede yapıldığı ve yöntemi hakkındaki bilgiler aşağıdaki Tablo 2' deki gibidir:

\begin{tabular}{|c|c|c|c|c|c|c|c|}
\hline $\begin{array}{l}\mathbf{N} \\
\mathbf{u}\end{array}$ & Künye & $\begin{array}{l}\text { Yazarların } \\
\text { Ülke/leri }\end{array}$ & Yilı & Türü & Çalışmanın Başlığı & $\begin{array}{l}\text { Çalışmanın } \\
\text { Yapıldığı } \\
\text { Ülke }\end{array}$ & Yöntem \\
\hline 1 & $\begin{array}{l}\text { Chaturvedi S. } \\
\text { \& Randive B. }\end{array}$ & $\begin{array}{l}\text { Hindistan, } \\
\text { Birleşik } \\
\text { Devletler }\end{array}$ & 2011 & Makale & $\begin{array}{l}\text { Public Private Partnerships for } \\
\text { Emergency Obstetric Care: } \\
\text { Lessons From Maharashtra }\end{array}$ & Hindistan & $\begin{array}{l}\text { Nitel } \\
\text { Yöntem }\end{array}$ \\
\hline 2 & $\begin{array}{l}\text { Barrows D., } \\
\text { MacDonald H. } \\
\text { I., Supapol A. } \\
\text { B., Dalton-Jez } \\
\text { O. \& Harvey- } \\
\text { Rioux S. }\end{array}$ & Kanada & 2012 & Makale & $\begin{array}{l}\text { Public-Private Partnerships in } \\
\text { Canadian Health Care: A Case } \\
\text { Study of the Brampton Civic } \\
\text { Hospital }\end{array}$ & Kanada & $\begin{array}{c}\text { Nitel } \\
\text { Yöntem }\end{array}$ \\
\hline 3 & Gupta M. & Hindistan & 2012 & Makale & $\begin{array}{l}\text { Successes and Failures of Public } \\
\text { Private Partnership (PPP) } \\
\text { Initiatives in Bihar }\end{array}$ & Hindistan & $\begin{array}{l}\text { Nitel } \\
\text { Yöntem }\end{array}$ \\
\hline 4 & $\begin{array}{l}\text { Şenel Tekin P. \& } \\
\text { Çelik Y. }\end{array}$ & Türkiye & 2012 & Makale & $\begin{array}{l}\text { Türkiye'de Sağlık Sektöründe } \\
\text { Bir Finansman Yöntemi Olarak } \\
\text { Kamu-Özel Ortaklığı } \\
\text { Politikasının Politika Haritalama } \\
\text { Yöntemi İle Analiz Edilmesi }\end{array}$ & Türkiye & $\begin{array}{c}\text { Nitel } \\
\text { Yöntem }\end{array}$ \\
\hline 5 & $\begin{array}{l}\text { Shadpour P., } \\
\text { Barzegar M. \& } \\
\text { Afzal E. }\end{array}$ & İran & 2013 & Makale & $\begin{array}{l}\text { Study on the Impact of } \\
\text { Implementing Public-Private } \\
\text { Partnership (PPP) at } \\
\text { Hasheminejad Kidney Center }\end{array}$ & İran & $\begin{array}{l}\text { Nicel } \\
\text { Yöntem }\end{array}$ \\
\hline 6 & $\begin{array}{l}\text { Ricks } \\
\text { Rooyen } \\
\text { Gantsho M. } \\
\text { Ham } \text { P. } \\
\text { Ham }\end{array}$ & $\begin{array}{l}\text { Güney } \\
\text { Afrika }\end{array}$ & 2013 & Makale & $\begin{array}{l}\text { Experiences of Managers and } \\
\text { Healthcare Personnel Involved } \\
\text { in A Functional Healthcare } \\
\text { Public Private Partnership }\end{array}$ & $\begin{array}{l}\text { Güney } \\
\text { Afrika }\end{array}$ & $\begin{array}{c}\text { Nitel } \\
\text { Yöntem }\end{array}$ \\
\hline 7 & $\begin{array}{l}\text { Baig M. B., } \\
\text { Panda B., Das J. } \\
\text { K. \& Chauhan } \\
\text { A. S. }\end{array}$ & Hindistan & 2014 & Makale & $\begin{array}{l}\text { Is Public Private Partnership an } \\
\text { Effective Alternative to } \\
\text { Government in the Provision of } \\
\text { Primary Health Care? A Case } \\
\text { Study in Odisha }\end{array}$ & Hindistan & $\begin{array}{l}\text { Karma } \\
\text { Yöntem }\end{array}$ \\
\hline 8 & $\begin{array}{lr}\text { McIntosh } & \text { N., } \\
\text { Grabowski } & \text { A., } \\
\text { Jack } & \text { B., } \\
\text { Nkabane- } & \\
\text { Nkholongo E. L. } \\
\text { \& Vian T. }\end{array}$ & $\begin{array}{c}\text { Birleşik } \\
\text { Devletler }\end{array}$ & 2015 & Makale & $\begin{array}{l}\text { A Public-Private Partnership } \\
\text { Improves Clinical Performance } \\
\text { in A Hospital Network in } \\
\text { Lesotho }\end{array}$ & $\begin{array}{l}\text { Lesotho } \\
\text { Krallığ1 }\end{array}$ & $\begin{array}{l}\text { Karma } \\
\text { Yöntem }\end{array}$ \\
\hline 9 & Öge H. \& Baş T. & Türkiye & 2016 & Makale & $\begin{array}{l}\text { Public-Private Partnership } \\
\text { Healthcare Projects in Turkey }\end{array}$ & Türkiye & $\begin{array}{l}\text { Nitel } \\
\text { Yöntem }\end{array}$ \\
\hline 10 & $\begin{array}{l}\text { Caballer- } \\
\text { Tarazona M. \& } \\
\text { Vivas-Consuelo } \\
\text { D. }\end{array}$ & İspanya & 2016 & Makale & $\begin{array}{l}\text { A Cost and Performance } \\
\text { Comparison of Public Private } \\
\text { Partnership and Public } \\
\text { Hospitals in Spain }\end{array}$ & İspanya & $\begin{array}{l}\text { Nicel } \\
\text { Yöntem }\end{array}$ \\
\hline
\end{tabular}




\begin{tabular}{|c|c|c|c|c|c|c|c|}
\hline 11 & Alonazi W. B. & $\begin{array}{l}\text { Suudi } \\
\text { Arabistan }\end{array}$ & 2017 & Makale & $\begin{array}{l}\text { Exploring Shared Risks Through } \\
\text { Public-Private Partnerships in } \\
\text { Public Health Programs: A } \\
\text { Mixed Method }\end{array}$ & $\begin{array}{l}\text { Suudi } \\
\text { Arabistan }\end{array}$ & $\begin{array}{l}\text { Karma } \\
\text { Yöntem }\end{array}$ \\
\hline 12 & $\begin{array}{l}\text { Borizovska I. B. } \\
\text { \& Kekenovski } \\
\text { L. }\end{array}$ & $\begin{array}{c}\text { Kuzey } \\
\text { Makedonya }\end{array}$ & 2017 & Makale & $\begin{array}{l}\text { Enhancing the Macedonian } \\
\text { Health System through } \\
\text { Implementation of the } \\
\text { PublicPrivate Partnership Model }\end{array}$ & $\begin{array}{c}\text { Kuzey } \\
\text { Makedonya }\end{array}$ & $\begin{array}{l}\text { Karma } \\
\text { Yöntem }\end{array}$ \\
\hline 13 & $\begin{array}{l}\text { Çınar N. F., } \\
\text { Türkoğlu Ç. \& } \\
\text { Tütünsatar A. }\end{array}$ & Türkiye & 2017 & Makale & $\begin{array}{l}\text { Kamu-Özel Ortaklığı/İşbirliği } \\
\text { Modeli ve Sağlı Hizmetlerinin } \\
\text { Sunumunda } \\
\text { Memnuniyetinin Ölçülmesi: } \\
\text { Entegre Sağlı } \\
\begin{array}{l}\text { (Şehir Hampüsleri } \\
\text { Araştırma }\end{array}\end{array}$ & Türkiye & $\begin{array}{l}\text { Nicel } \\
\text { Yöntem }\end{array}$ \\
\hline 14 & $\begin{array}{l}\text { Ayhan E. \& } \\
\text { Önder E. }\end{array}$ & Türkiye & 2018 & Makale & $\begin{array}{l}\text { Türkiye'de Sağlık Sektöründe } \\
\text { Kamu Özel Ortaklığı Modeli }\end{array}$ & Türkiye & $\begin{array}{l}\text { Nitel } \\
\text { Yöntem }\end{array}$ \\
\hline 15 & $\begin{array}{l}\text { Gökkaya } \\
\begin{array}{l}\text { İzgüden } \\
\text { Erdem R. }\end{array}\end{array}$ & Türkiye & 2018 & Makale & $\begin{array}{l}\text { Şehir Hastanesinde Hasta } \\
\text { Memnuniyeti Araştırması: } \\
\text { Isparta İli Örneği }\end{array}$ & Türkiye & $\begin{array}{c}\text { Nicel } \\
\text { Yöntem }\end{array}$ \\
\hline 16 & $\begin{array}{l}\text { Sonğur. \& Top } \\
\text { M. }\end{array}$ & Türkiye & 2018 & Makale & $\begin{array}{l}\text { Türkiye'de Sağlı Sektöründe } \\
\text { Kamu-Özel İşbirliği Modeli: } \\
\text { Paydaş Görüşlerine Dayalı Bir } \\
\text { Alan Araştırması }\end{array}$ & Türkiye & $\begin{array}{l}\text { Karma } \\
\text { Yöntem }\end{array}$ \\
\hline 17 & Baş Ö. & Türkiye & 2018 & Tez & $\begin{array}{l}\text { Sağlık Sektöründe Kamu Özel } \\
\text { Ortaklığı Modeli Hakkında } \\
\text { Hizmet Sunucuları ve Hizmet } \\
\text { Yararlanıcılarının Görüşlerinin } \\
\text { Değerlendirilmesi: Yozgat illi } \\
\text { Örneği }\end{array}$ & Türkiye & $\begin{array}{l}\text { Nicel } \\
\text { Yöntem }\end{array}$ \\
\hline 18 & $\begin{array}{l}\text { Özzeybek Taş } \\
\text { M. }\end{array}$ & Türkiye & 2018 & Tez & $\begin{array}{l}\text { Vatandaşların ve Sağlık } \\
\text { Çalışanlarının Şehir Hastaneleri } \\
\text { İle İlgili Görüşlerinin } \\
\text { Belirlenmesi: Ankara İli Örneği }\end{array}$ & Türkiye & $\begin{array}{l}\text { Nicel } \\
\text { Yöntem }\end{array}$ \\
\hline 19 & $\begin{array}{l}\text { Alwani J., } \\
\text { Stepurko T., } \\
\text { Anufriyeva V. \& } \\
\text { Shevchenko M. }\end{array}$ & $\begin{array}{l}\text { Misir, } \\
\text { Ukrayna, } \\
\text { Hollanda, } \\
\text { Avustralya }\end{array}$ & 2018 & Makale & $\begin{array}{l}\text { Perspective of Public-Private } \\
\text { Partnership in The Filed of } \\
\text { Healthcare in Ukraine }\end{array}$ & Ukrayna & $\begin{array}{l}\text { Nitel } \\
\text { Yöntem }\end{array}$ \\
\hline 20 & $\begin{array}{l}\text { Thiessen J., } \\
\text { Bagoi A., Homer } \\
\text { C. \& Rumsey M. }\end{array}$ & $\begin{array}{l}\text { Avustralya, } \\
\text { Papua Yeni } \\
\text { Gine }\end{array}$ & 2018 & Makale & $\begin{array}{l}\text { Qualitative Evaluation of A } \\
\text { Public-Private Partnership for } \\
\text { Reproductive Health Training in } \\
\text { Papua New Guinea }\end{array}$ & $\begin{array}{l}\text { Papua Yeni } \\
\text { Gine }\end{array}$ & $\begin{array}{c}\text { Nitel } \\
\text { Yöntem }\end{array}$ \\
\hline 21 & 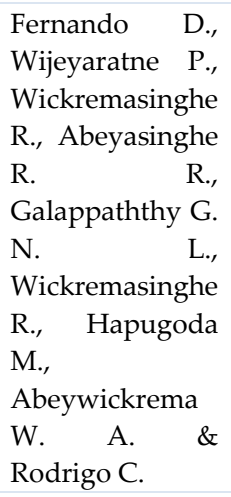 & $\begin{array}{l}\text { Sri Lanka, } \\
\text { Filipinler, } \\
\text { Vietnam }\end{array}$ & 2018 & Makale & $\begin{array}{l}\text { Use of A Public-Private } \\
\text { Partnership in Malaria } \\
\text { Elimination Efforts in Sri Lanka; } \\
\text { A Case Study }\end{array}$ & Sri Lanka & $\begin{array}{l}\text { Nitel } \\
\text { Yöntem }\end{array}$ \\
\hline 22 & $\begin{array}{l}\text { Khan N. N. \& } \\
\text { Puthussery S. }\end{array}$ & $\begin{array}{l}\text { Pakistan, } \\
\text { Birleşik } \\
\text { Krallık }\end{array}$ & 2019 & Makale & $\begin{array}{l}\text { Stakeholder Perspectives on } \\
\text { Public-Private Partnership in } \\
\text { Health Service Delivery in Sindh } \\
\text { Province of Pakistan: A } \\
\text { Qualitative Study }\end{array}$ & Pakistan & $\begin{array}{l}\text { Nitel } \\
\text { Yöntem }\end{array}$ \\
\hline
\end{tabular}




\begin{tabular}{|c|c|c|c|c|c|c|c|}
\hline 23 & Yilmaz A. & Türkiye & 2019 & Tez & $\begin{array}{l}\text { Hastanelerde Veri Zarflama } \\
\text { Analizi ve Malmquist Endeksi } \\
\text { Yöntemi İle Performans } \\
\text { Ölçümü: Mersin Şehir Eğitim } \\
\text { Araştırma Hastanesi Örneği }\end{array}$ & Türkiye & $\begin{array}{l}\text { Nicel } \\
\text { Yöntem }\end{array}$ \\
\hline 24 & Önder E. & Türkiye & 2019 & Tez & 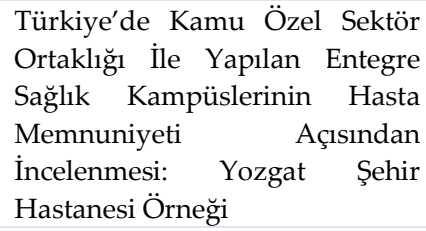 & Türkiye & $\begin{array}{l}\text { Nicel } \\
\text { Yöntem }\end{array}$ \\
\hline 25 & $\begin{array}{l}\text { Asasira J. \& } \\
\text { Ahimbisibwe F. }\end{array}$ & Uganda & 2019 & Makale & $\begin{array}{l}\text { Public-Private Partnership in } \\
\text { Health Care and its Impact on } \\
\text { Health Outcomes: Evidence } \\
\text { from Ruharo Mission Hospital } \\
\text { in South Western Uganda }\end{array}$ & Uganda & $\begin{array}{l}\text { Nitel } \\
\text { Yöntem }\end{array}$ \\
\hline 26 & $\begin{array}{l}\text { Uğurluoğlu D., } \\
\text { Gökkaya D. \& } \\
\text { Erdem R. }\end{array}$ & Türkiye & 2019 & Makale & $\begin{array}{l}\text { Şehir Hastanesinde Çalışan } \\
\text { Memnuniyeti Araştırması }\end{array}$ & Türkiye & $\begin{array}{l}\text { Nicel } \\
\text { Yöntem }\end{array}$ \\
\hline 27 & $\begin{array}{l}\text { Gharaee H., } \\
\text { Tabrizi J. S., } \\
\text { Azami-Aghdash } \\
\text { S., Farahbakhsh } \\
\text { M., Karamouz } \\
\text { M. r \& } \\
\text { Nosratnejad S. }\end{array}$ & İran & 2019 & Makale & $\begin{array}{l}\text { Analysis of Public-Private } \\
\text { Partnership in Providing } \\
\text { Primary Health Care Policy: An } \\
\text { Experience From Iran }\end{array}$ & İran & $\begin{array}{l}\text { Nitel } \\
\text { Yöntem }\end{array}$ \\
\hline 28 & $\begin{array}{l}\text { Laar A. K., } \\
\text { Adler A. J., } \\
\text { Kotoh A. M., } \\
\text { Legido-Quigley } \\
\text { H., Lange I. L., } \\
\text { Perel P. \& } \\
\text { Lamptey P. }\end{array}$ & $\begin{array}{l}\text { Gana, } \\
\text { Birleşik } \\
\text { Devletler, } \\
\text { İspanya, } \\
\text { Birleşik } \\
\text { Krallık }\end{array}$ & 2019 & Makale & $\begin{array}{l}\text { Health System Challenges to } \\
\text { Hypertension and Related Non- } \\
\text { Communicable } \\
\text { Prevention and Treatment: } \\
\text { Perspectives From Ghanaian } \\
\text { Stakeholders }\end{array}$ & Gana & $\begin{array}{l}\text { Nitel } \\
\text { Yöntem }\end{array}$ \\
\hline 29 & $\begin{array}{l}\text { Shannon G. D., } \\
\text { Haghparast- } \\
\text { Bidgoli H., } \\
\text { Chelagat W., } \\
\text { Kibachio J. \& } \\
\text { Skordis-Worrall } \\
\text { J. }\end{array}$ & $\begin{array}{l}\text { Birleşik } \\
\text { Krallık, } \\
\text { İsveç, } \\
\text { İsviçre }\end{array}$ & 2019 & Makale & $\begin{array}{l}\text { Innovating to Increase Access to } \\
\text { Diabetes Care in Kenya: An } \\
\text { Evaluation of Novo Nordisk's } \\
\text { Base of the Pyramid Project }\end{array}$ & Kenya & $\begin{array}{l}\text { Nitel } \\
\text { Yöntem }\end{array}$ \\
\hline 30 & Tenşi M. & Türkiye & 2019 & Tez & \begin{tabular}{lr} 
Sağlık Sektöründe & \multicolumn{2}{c}{ Kamu-Özel } \\
Ortaklığı Modelinin & Şehir \\
Hastaneleri & Ekseninde \\
Değerlendirilmesi: İzmir Alan \\
Çalışması
\end{tabular} & Türkiye & $\begin{array}{l}\text { Nicel } \\
\text { Yöntem }\end{array}$ \\
\hline 31 & $\begin{array}{l}\text { Chemtob D., } \\
\text { Rich R., Harel } \\
\text { N., Averick N., } \\
\text { Schwartzberg E., } \\
\text { Yust I., Maayan } \\
\text { S., Grotto I. \& } \\
\text { Gamzu R. }\end{array}$ & İsrail & 2019 & Makale & \begin{tabular}{llr} 
Ensuring & HIV & \multicolumn{1}{c}{ Care to } \\
Undocumented & Migrants in \\
Israel: A & Public-Private \\
Partnership Case Study
\end{tabular} & İsrail & $\begin{array}{l}\text { Nitel } \\
\text { Yöntem }\end{array}$ \\
\hline 32 & Ersoy L. & Türkiye & 2020 & Tez & $\begin{array}{l}\text { Bir Kamu Hastanesi'nde Çalışan } \\
\text { Yoğun Bakım Hemşirelerinin İ̧̧ } \\
\text { Ve Yaşam Doyumları İle Ekip } \\
\text { Çalışması Tutumları Arasındaki } \\
\text { İlişkinin İncelenmesi }\end{array}$ & Türkiye & $\begin{array}{l}\text { Nicel } \\
\text { Yöntem }\end{array}$ \\
\hline 33 & $\begin{array}{l}\text { Nuhu S., } \\
\text { Mpambije C. J. } \\
\text { \& Ngussa K. }\end{array}$ & $\begin{array}{l}\text { İsveç, } \\
\text { Tanzanya }\end{array}$ & 2020 & Makale & $\begin{array}{l}\text { Challenges in Health Service } \\
\text { Delivery Under Public-Private } \\
\text { Partnership in Tanzania: } \\
\text { Stakeholders' Views From Dar } \\
\text { Es Salaam Region }\end{array}$ & Tanzanya & $\begin{array}{l}\text { Nitel } \\
\text { Yöntem }\end{array}$ \\
\hline
\end{tabular}




\begin{tabular}{|c|c|c|c|c|c|c|c|}
\hline 34 & $\begin{array}{l}\text { Yang J., Song L., } \\
\text { Yao X., Cheng } \\
\text { Q., Cheng Z. \& } \\
\text { Xu K. }\end{array}$ & $\begin{array}{c}\text { Birleşik } \\
\text { Krallık, Çin }\end{array}$ & 2020 & Makale & $\begin{array}{l}\text { Evaluating the Intention and } \\
\text { Behaviour of Private Sector } \\
\text { Participation in Healthcare } \\
\text { Service Delivery via Public- } \\
\text { Private Partnership: Evidence } \\
\text { from China }\end{array}$ & Çin & $\begin{array}{c}\text { Nicel } \\
\text { Yöntem }\end{array}$ \\
\hline 35 & $\begin{array}{l}\text { Ortega-Díaz M. } \\
\text { I., Ocaña-Riola } \\
\text { R., Pérez- } \\
\text { Romero C. \& } \\
\text { Martín-Martín J. } \\
\text { J. }\end{array}$ & İspanya & 2020 & Makale & 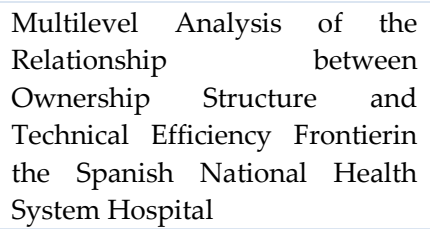 & İspanya & $\begin{array}{c}\text { Nicel } \\
\text { Yöntem }\end{array}$ \\
\hline
\end{tabular}

Tablo 2'ye göre araştırmaya makale ve tezler oluşan 35 çalışma dâhil edilmiştir. İlerleyen aşamalarda bu çalışmalar içerik analiziyle belirlenen temalar çerçevesinde incelenmiştir.

\subsection{Araştırmaların Yayınlandığı Yıla Ait Bulgular}

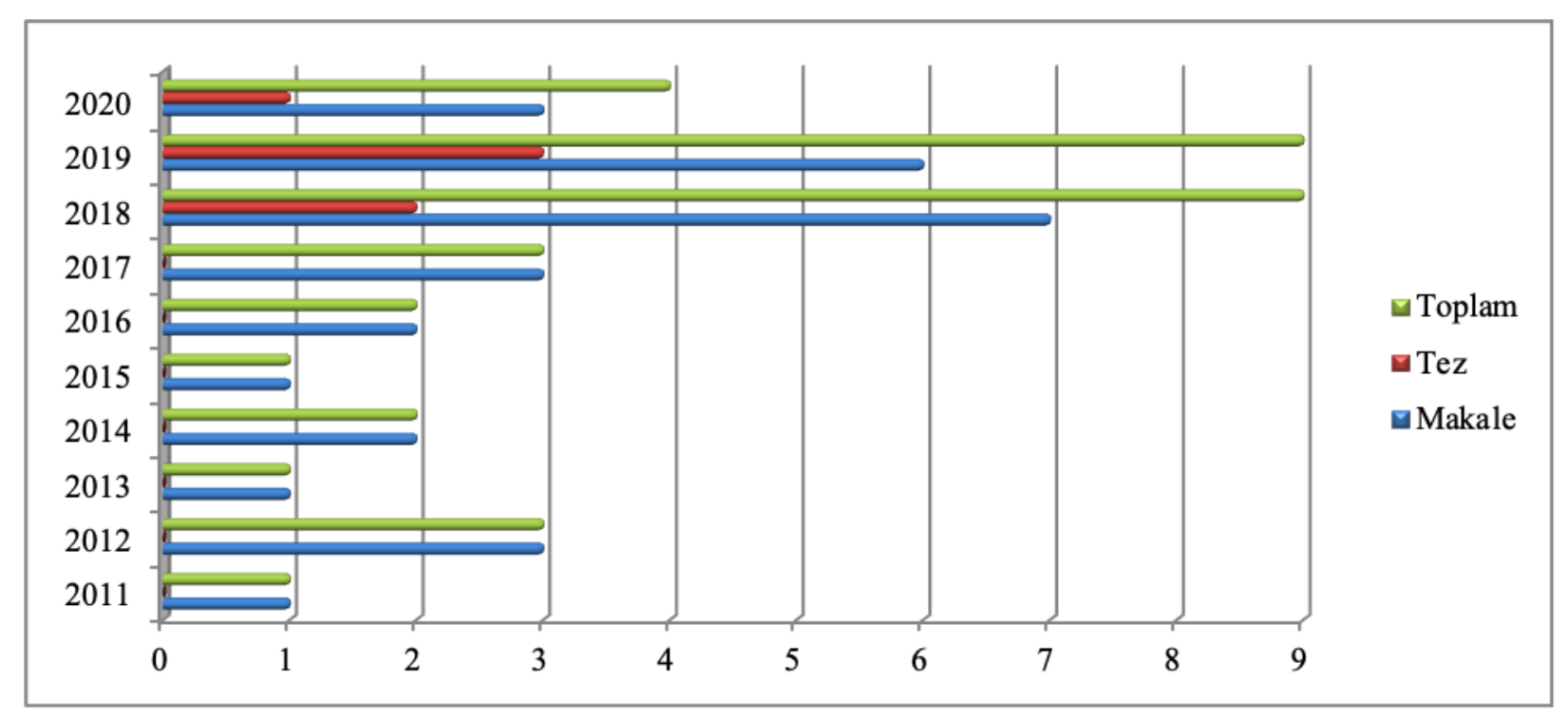

Grafik 1. Araştırmaların Yayınlandığı Yıla Ait Bulgular 
Grafik 1 incelendiğinde, 2011 ve 2017 yılları arasında sadece makale türünden çalışmalar yapıldı ̆̆ı anlaşılmaktadır. 2018 yılı itibariyle 7 makale ve 2 tez, 2019 yılında 6 makale ve 3 tez, son olarak da 2020 yılında 3 makale ve 1 tez çalışması yapıldığ görülmektedir.

\subsection{Araştırmaların Amacına İlişkin Bulgular}

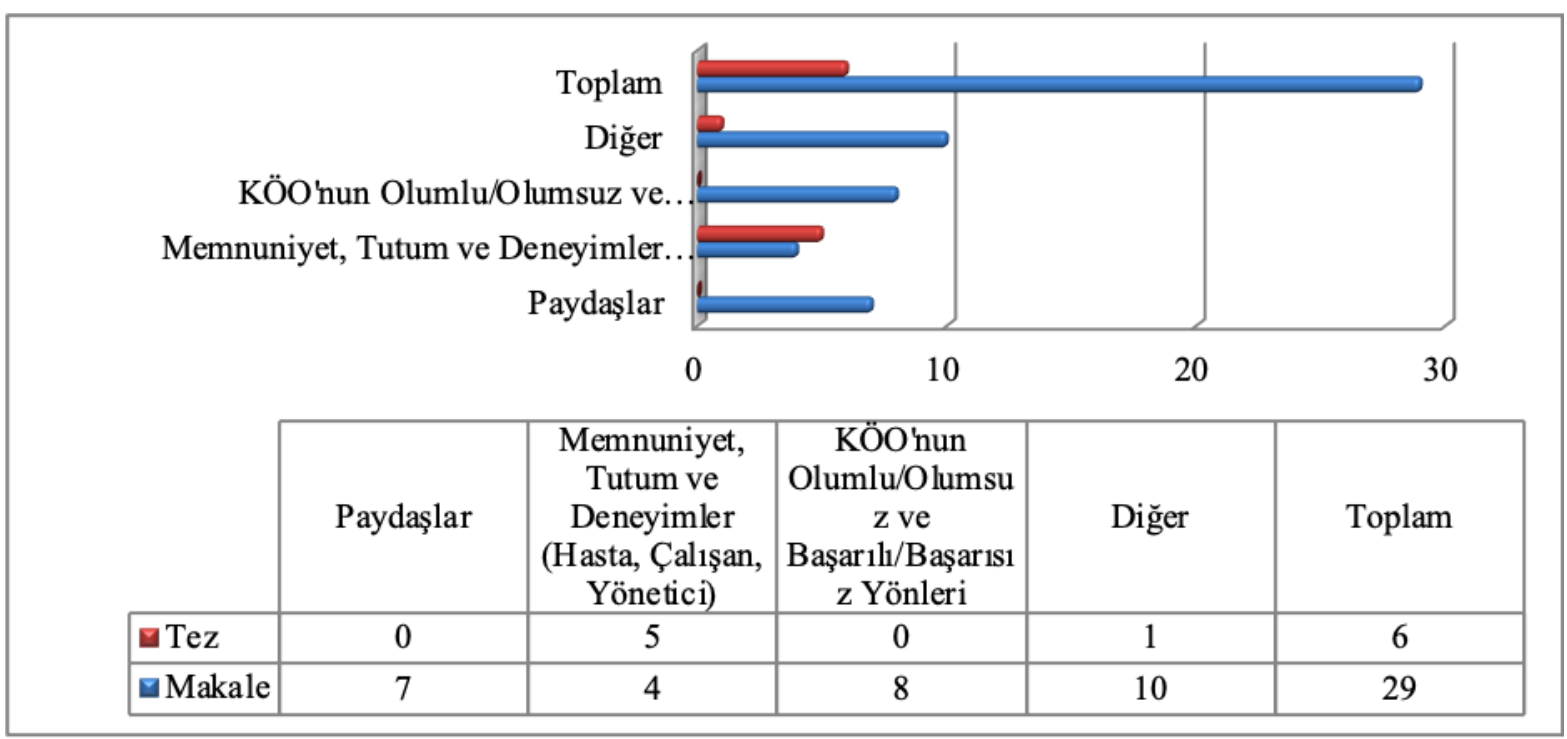

Grafik 2. Araştırmaların Amacına İlişkin Bulgular

Grafik 2'ye bakıldığında, çalışmaların konusu incelendiğinde 10 makale ile en çok diğer adlı grupta (KÖO ile kamu hastanelerinin maliyet ve performansının karşılaştırılması, KÖO sağlık projeleri için banka çalışanları ile görüşme yapılması, Mersin Şehir Eğitim ve Araştırma Hastanesi'nde Veri Zarflama Analizi ve Malmquist Endeksi Yöntemi ile performans ölçülmesi vs.) yayın bulunmaktadır. KÖO'nun olumlu/olumsuz ve başarılı/başarısız yönleri ile ilgili 8 makale çalışması; paydaşlar teması ile ilgili olarak 7 makale ve son olarak memnuniyet, tutum ve deneyimler (hasta, çalışan, yönetici) kapsamında ise 4 makale yer almaktadır.

Grafik 2'de tezlerin amaçlarına yönelik sırasıyla memnuniyet, tutum ve deneyimler (hasta, çalışan, yönetici) 5, diğer adlı temada ise 1 çalışma yer aldığı görülmektedir.

Araştırmaya dâhil edilen çalışmalarda çok çeşitli konuların ele alındığı tespit edilmiştir. Farklı ülkelerde (Türkiye, Sri Lanka, Hindistan, Tanzanya vs.) sağlık sektöründe çeşitli uygulamalar gerçekleştirildiği gözlemlenmektedir. Kamu özel ortaklığ1 modeli son yıllarda oldukça ilgi görmekte ve güncelliğini de korumaya devam edeceği düşünülmektedir. Dünya genelinde nüfusun artmasıyla beraber her geçen yıl yükselen sağlık harcamalarının devletlerin, özel sektör ile daha fazla işbirliği yapmalarına sebep olacağ tahmin edilmektedir.

\subsection{Araştırmaların Yöntemine İlişkin Bulgular}




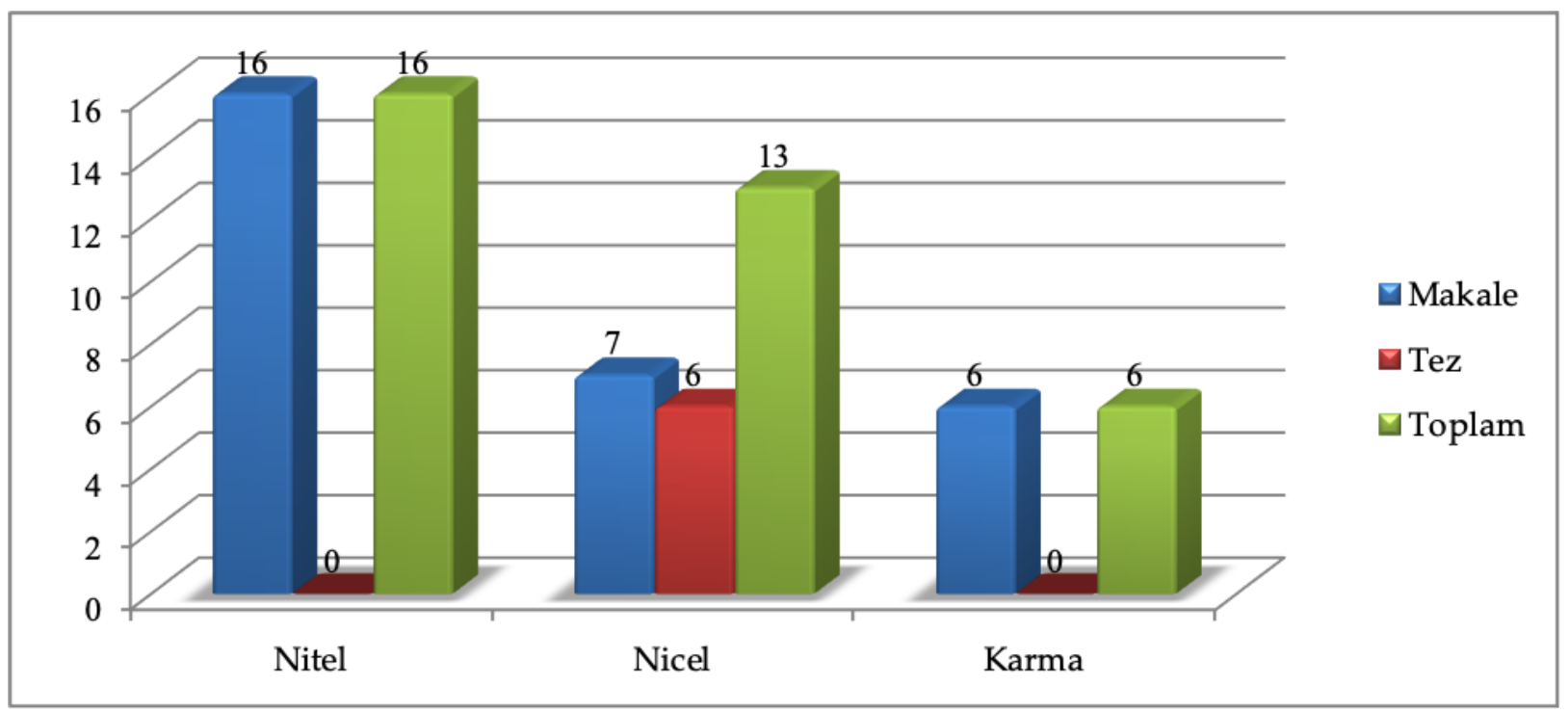

Grafik 3. Araştırmaların Yöntemine İlişkin Bulgular

Grafik 3'te görüldüğü üzere sağlık sistemlerinde kamu özel ortaklığına ilişkin \%46 oranıyla nitel yöntem $(n=16)$ kullanılmıştır. Nitel yöntem olarak mülakat, vaka çalışması, gözlem, odak grup görüşmesi, betimsel analiz ve içerik analizi tekniklerinden yararlanılmıştır.

\%37 oranı ile nicel araştırma yöntemi $(n=13)$ tercih edilmiştir. Nicel yöntem olarak anket, ikincil veriler, Veri Zarflama Analizi (VZA) ile Malmquist Endeksi Yöntemi, koveryans tabanlı yapısal denklem modellemesi kullanılmıştır.

\%17 oranı ile karma yöntem $(n=6)$ çalışması bulunmaktadır. Karma yöntemden faydalanılan yayınlarda nitelden nicele (mülakat, saha incelemesi, anket veya mülakat, gözlem, hasta kayıtları veya görüşme tekniği, anket) ve nicelden nitele bir yöntem (anket, ikincil veriler, vaka çalışması) kullanıldığı görülmektedir.

\subsection{Araştırmaların Bulguları}

Araştırma süresince değerlendirilen 35 çalışmada kamu özel ortaklığı hakkında farklı bulgulara ulaşılmıştır. Bu bölümde, yayınlardaki bulguların amaçlar doğrultusunda avantaj ve dezavantaj alt temalarına ayrılmıştır. 


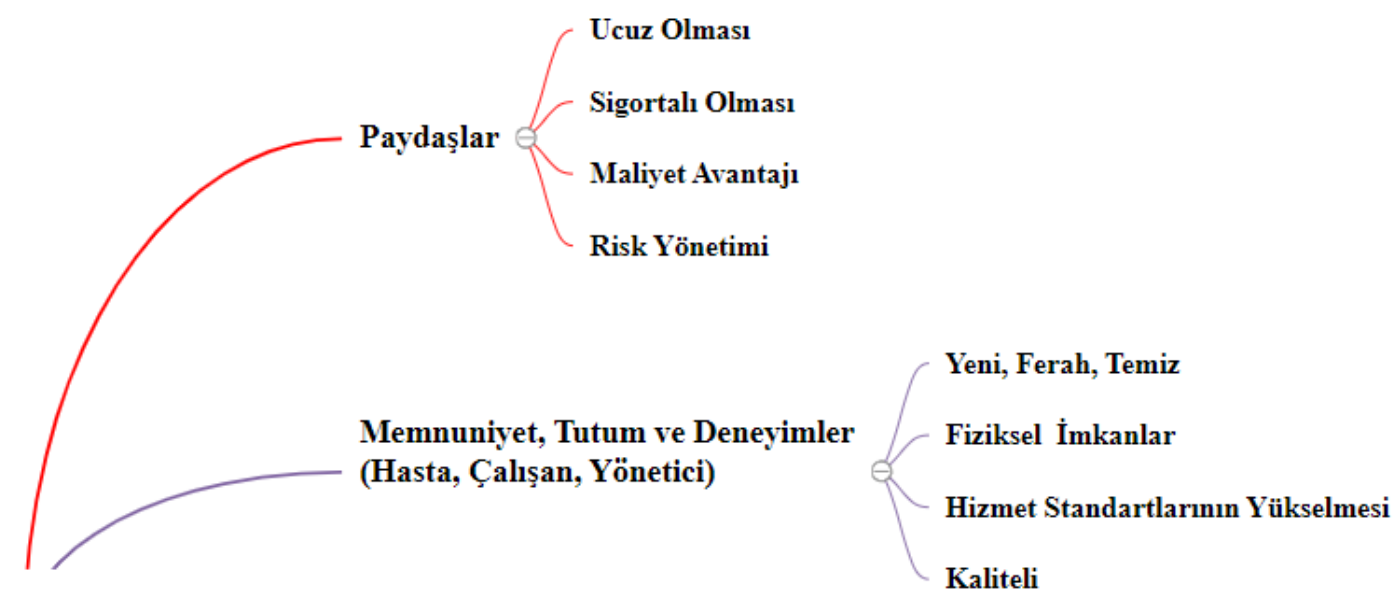

Kamu-Özel Ortaklığının

Avantajları

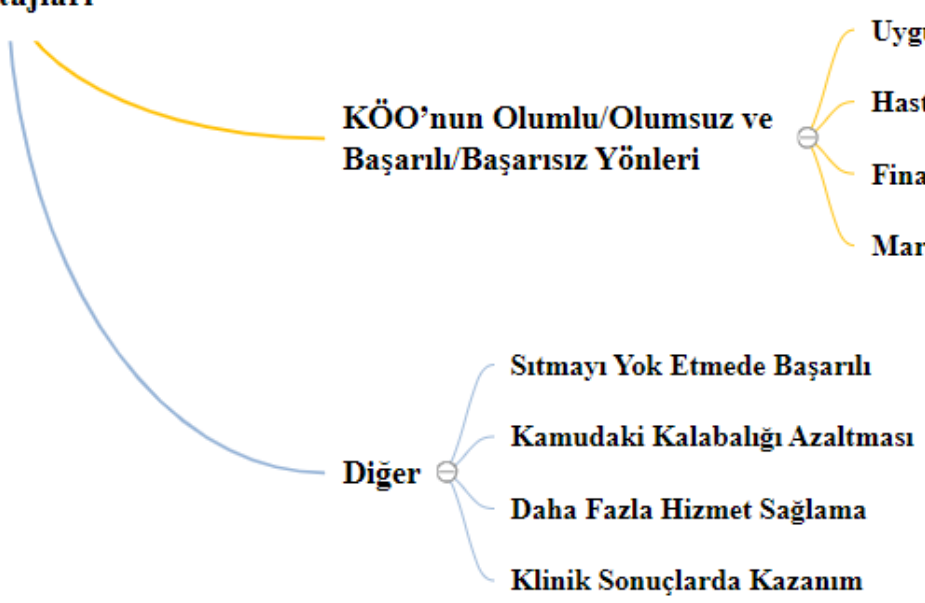

Şekil 1. Kamu-Özel Ortaklığının Avantajları

Paydaşlar teması altında toplam 7 yayın bulunmaktadır. Her bir yayını tek tek incelemekten ziyade, genel bir değerlendirme yapılmıştır. KÖO'nun öne çıkan avantajları içerisinde ucuz olması, sigortalı olması, tıbbi hizmet için vatandaşlardan ilave bir ücret istenmemesi, maliyet avantajı, projenin zamanında teslimi, kaynak tasarrufu ve risk yönetimi gibi bulgular elde edilmiştir.

Memnuniyet, tutum ve deneyimler (hasta, çalışan, yönetici) adlı temada 9 çalışma yer almaktadır. KÖO'nun olumlu yönleri; temiz/hijyenli olması, personel yönlendirme elemanlarının olması; rahat, güvenli, yeni, ferah, kaliteli olması, fiziksel imkânları olması, ilk başvuru noktasının kolayca bulunabilmesi; hasta bakıcı ve hizmetlilerin ilgili, hoşgörülü ve saygılı olması, hizmet standartlarını yükselmesi ve ortaklara fayda sağlaması şeklindedir.

KÖO'nun olumlu/olumsuz ve başarılı/başarısız yönleri ile ilgili temada toplamda 8 çalışma bulunmaktadır. Şehir hastaneleri hakkındaki görüşler hasta ve yöneticiler açısından olumlu bir perspektife hâkimdir. Finansal anlamda iyileşme olduğu, KÖO sayesinde sıtmayı yok etmede başarılı olunduğu, hastane hizmetlerine ve personele fayda sağlanıldığı, güçlü ilişkiler ve resmi karar verme organlarına sahip olunduğu; özerklik, markalaşma, kurumsal sahiplenme, şeffaflık ve standardizasyon oluştuğu ve son olarak uygulanabilir politika olduğu bulgularına ulaşılmıştır. 
Diğer adlı temada ise 11 yayına erişilmiştir. Çalışmaların ortak yönleri az olduğu için bu tema altında toplanması uygun görülmüştür. Kamu özel ortaklığı ile yapılan şehir hastanesinin (23) performansı ölçülmüş ve girdi artışı hastanenin yeni olmasından kaynaklanırken; çıktının azalmasının ise mevsimsel olduğu tespit edilmiştir. Özel sektörün hizmet sunumuna dâhil olması ile kamudaki kalabalığın azaltmada etkili olduğu ve KÖO modeli ile daha fazla hizmeti kaliteli sunulduğu ve klinik sonuçlarda önemli kazanım sağlandığı ve kayda değer bir verimliliğe ulaşıldığı tespit edilmiştir.

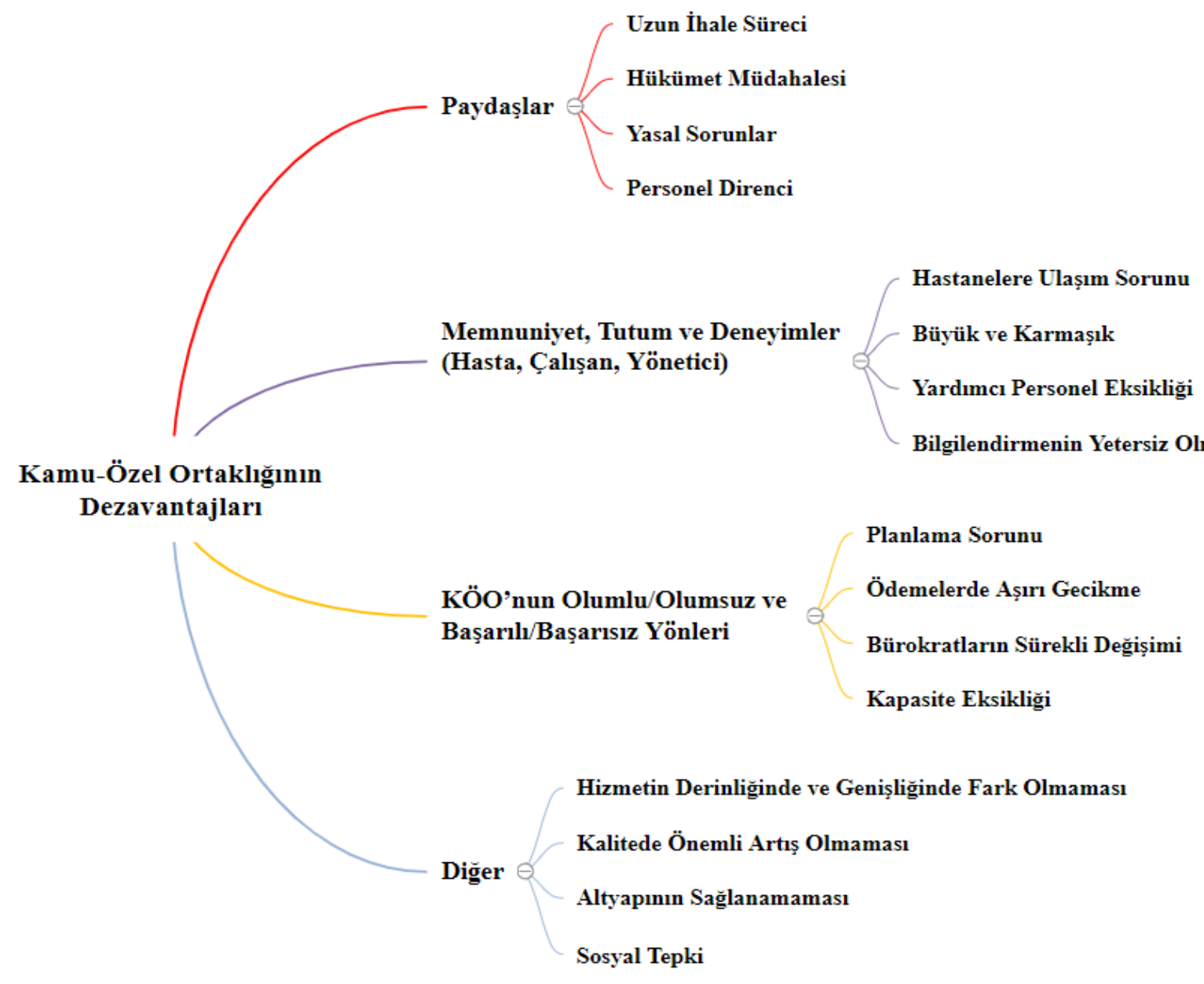

Şekil 2. Kamu-Özel Ortaklığının Dezavantajları

Paydaşlar temasının dezavantajları ise uzun ihale süreci, toplum şikâyeti, hükümet müdahalesi, yetersiz kaynak ve iletişim, paydaşlarda güven eksikliği, yasal sorunlar, personel direncidir.

Memnuniyet, tutum ve deneyimler (hasta, çalışan, yönetici) adlı temanın olumsuz yönleri ise hastanelere erişimde ulaşım sorunu, hastanenin büyük ve karmaşık olması, yardımcı personel eksikliği, iş yükü artışı, idari personelin yetersizliği, sağlık hizmetlerini zamanında alamamak/sıra beklemek, özel ilginin yetersiz olması, model hakkında çalışanların bilgilerinin yetersiz olması sayılabilir. KÖO yöntemine ilişkin bakış açıları hasta ve yöneticiler şehir hastanelerine bakış açıları daha pozitif iken, sağlık çalışanları görece daha negatif olduğu görülmüştür. Bunun kanıtı ise 26 numaralı çalışmada tespit edilen, sağlık çalışanları şehir hastanesine taşınmadan evvelki hastanelerinde daha memnun olduklarını ifade etmiş olmalarıdır. 
KÖO'nun olumlu/olumsuz ve başarılı/başarısız yönleri ile ilgili temada, kamu sektörünün KÖO girişimlerini izlemede kaynaktan yoksun olması, planlama sorunu, ödemelerde aşırı gecikme, bürokratların sürekli değişimi, yönetişim çerçevesinin eksikliği, kurumsal kültürde farklılıklar, kapasite eksikliği, uygulayıcıların altyapı yetersizlikleri, KÖO'yu tasarlamada ve yönetmede yetersizlikler olduğu tespit edilmiştir.

Diğer adlı temada ise bu model ile verilen hizmetlerin genişliği ve derinliği bakımından fark olmadığı, kalitede önemli bir artışın ve altyapının sağlanamadığı tespit edilmiştir. Bir çalışmada (9) KÖO projelerini finans eden bankaların müdürleri ile yapılan mülakatta, sosyal refaha katkı sağlayacağ 1 için projeleri desteklediklerini belirtirken başka bir banka müdürü ise borçların ödenememesi durumunda hastane yataklarının teminat olarak alınması halinde sosyal tepkiye yol açacağını belirtmiştir.

\subsection{Araştırmaların Önerileri}

Kamu özel ortaklığı 1980'li yıllardan itibaren yaygınlık kazanmaya başlayan bir modeldir. Birçok ülkede bu modelin farklı uygulamalarına rastlamak mümkündür. Araştırmaların önerilerini üç tema altında toplamak mümkündür;

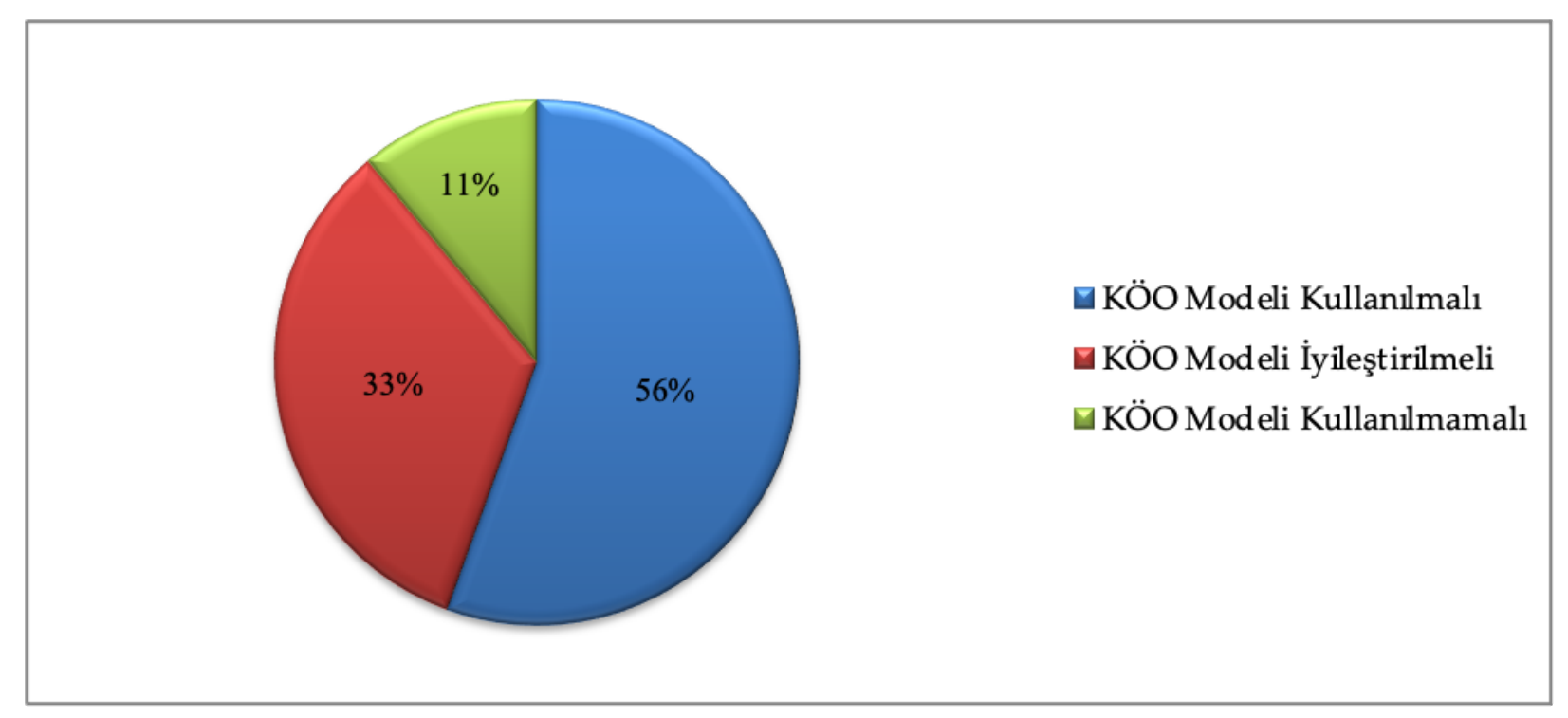

Grafik 4. Araştırmaların Önerileri

Grafik 4'e göre yayınlarda belirtilen önerilerden yola çıkarak kamu özel ortaklığı modeli hakkında üç genel görüş yer almaktadır. İlk olarak, kamu özel ortaklığı kullanılmalı adlı temada kamu yararı sağlandığı, uygulanabilir bir politika olduğu, modeli desteklemek ve geliştirmek gerektiği ve iyileştirme fırsatları sunabileceği belirtilmiştir. İkinci olarak, kamu özel ortaklığ yol açabileceği için şehir hastanesi ile koordineli çalışan semt polikliniklerinin ve özel hastanelerin kapsamının daraltılması, modeli kullanırken dikkatli olunması ve özellikle sağlık alanında daha da titiz davranılması gerektiğine yer verilmiştir. Son olarak kamu özel ortaklığı modeli kullanılmamalı adlı başlıkta ise hizmet sunucularının kamuya yük getireceği endişesi yer almaktadır. Çalışmaların sunduğu öneriler: 
- Şehir hastanesinin ulaşım sorunu için yerel yönetimlerle işbirliği yapılması, yardımcı sağlık personeli istihdam edilmesi, hastane içindeki iletişim sorunları için altyapının oluşturulması, yönlendirme faaliyetlerin artırılması gerektiği (Gökkaya vd., 2018: 146);

- KÖO modeliyle yapılan şehir hastaneleri ile koordineli çalıştığı için semt polikliniklerinin ve özel hastanelerinin kapsamının daraltılması (Sonğur ve Top, 2018: 182);

- Şehir hastanesinin öncesi ve sonrası için maliyetler hesaplanıp, karşılaştırma yapıldıktan sonra fayda getirip getirmediğine bakılmalıdır. Sağlık çalışanlarına KÖO modeli hakkında daha fazla bilgilendirme yapılması gerektiği ve yöneticiler şeffaf yönetim anlayışı çerçevesinde çalışanlara gelişmeler hakkında haber vermeleri gerektiği (Baş, 2018: 73);

- KÖO projelerini planlarken özen gösterilmesi ve bu projeleri sağlık alanında uygularken daha titiz davranılması gerektiği (Özzeybek Taş, 2018: 56);

- Kamu özel ortaklığı yönteminin sıtma hastalığını yok etmedeki başarısı sayesinde bu modelin bölgedeki diğer ülkeler için kullanılabileceği (Fernando vd., 2018: 9);

- Kamu özel işbirliğinde taraflar arasında güç dengesizliklerinin nasıl üstesinden gelineceği hakkında araştırma yapılması tavsiye edilmektedir (Thiessen vd., 2018).

\section{SONUÇ VE DEĞERLENDİRME}

Kamu özel ortaklığı modeli, 1980'lerden sonra popülerlik kazanmasıyla birçok ülkenin altyapı yatırımlarında kullanılmaya başlanmıştır. Bu model sayesinde, yapılacak olan yeni yatırımlar için risk paylaşımının yapılması, sermayenin harekete geçirilmesi, özel sektörün uzmanlığı ve deneyimi ile kamunun politika yapma ve planlama yeteneğinin birleşmesiyle kamu hizmetlerinin daha hızlı, kaliteli, etkin ve verimli olması sağlanmaktadır.

1930'larda müdahaleci sosyal devlet ile birlikte sağlık hizmetleri ücretsiz bir şekilde sunulmaya başlanmış ve devletler hizmet sunumunda büyük roller üstlenmişlerdir. Fakat kamusal harcamaların artması nedeniyle vergilerin yükselmesi durumu, sosyal devlet anlayışının yerini 1980'li yıllarda düzenleyici devlet anlayışına bırakmıştır. 1979'da İngiltere' de Thatcher, 1980'de Amerika'da Reagan döneminde kamu yönetimi anlayışında bir dönüşüm yaşanmış ve devletlerin kamu hizmetlerindeki hâkimiyeti azalmıştır. 2000'lerden sonra yönetişim anlayışına sahip devlet dönemi ile uluslararası kuruluşlar, kamu hizmetleri için yapılması düşünülen kamu özel ortaklığı projelerini finanse etmeye başlamışlardır.

20. yüzyılda neoliberal politikalarla kullanım alanı genişleyen kamu özel ortaklı̆̆ı, devletlerin kamu hizmetlerini gerçekleştirmede kaynak yetersizliği yaşamaları, halkın kalite hizmet beklentisini karşılayamamaları ve sağlık harcamalarında yaşanan artış sebebiyle özel sektör ile işbirliği yapar hale gelmişlerdir. Ekonomik kriz sonrası uluslar ciddi mali zorluklarla baş etmek ve ulaşım, su ve atık su, havalimanı ve enerji gibi altyapı yatırımlarının yüksek maliyetinden dolayı alternatif bir finansman modeli arayışına girmişlerdir. Sağlık sektöründe de devletler; vatandaşlarının memnuniyetini artıracak kaliteli ve ileri teknolojili sağlık hizmeti sunabilmek için kamu özel ortaklıklarını tercih etmektedirler. 
Sağlık hizmetlerinde artan kullanımı nedeniyle kamu özel ortaklığı modeli ile ilgili paydaşların görüşleri, hizmetlere sağladığı avantaj ya da dezavantajların ortaya konulmasını gerektirmiştir. $\mathrm{Bu}$ bağlamda, modelin gelecekte uygulanıp uygulanmaması gerektiği veya iyileştirilmesi gereken sorunların neler olduğunun tespit edilmesi önem arz etmektedir.

$\mathrm{Bu}$ çalışma ile sağlık sistemi (health system), kamu-özel ortaklığı (public-private partnerships), entegre sağlık kampüsü (integrated health campus), sağlık kampüsü (health campus) ve şehir hastanesi (city hospital) anahtar kelimeleri ile yapılan literatür taraması sonucunda bulunan araştırmalar, nitel araştırma temel veri analiz tekniklerinden birisi olan içerik analizi ile incelenmiştir. Araştırmanın yayınlandığ1 yıl, amaç, yöntem, bulgu ve öneriler olarak beş kategoride değerlendirilmeye çalışılmıştır. Bu doğrultuda öne çıkan hususlar özetle şu şekildedir:

- Araştırmalar yayınladığı yıl açısından değerlendirildiğinde 2018 ve 2019 senelerinde yoğunlaştığı;

- Araştırmanın amaçları yönünden en çok çalışılan konu diğer adlı temada (KÖO ile kamu hastanelerinin maliyet ve performansının karşılaştırılması, KÖO sağlık projelerinin finansmanı sürecinde yer alan banka çalışanlarıyla görüşme yapılması vs.) yer aldiğı;

- Araştırmaların yöntemleri incelendiğinde kamu özel ortaklığı ile ilgili araştırmalarda \%46 oran ile nitel yöntem kullanıldı ğı;

- Araştırmanın bulguları açısından tek bir görüş olmadı̆̆ı tespit edilmiştir. KÖO modeli ile gerçekleştirilen hastanelerin temiz, rahat, güvenli ve ferah olması; sağlık hizmetlerinin de klinik sonuçlarda kazanımlar sağlaması, kamu hastanelerine kıyasla daha iyi olması, maliyet avantajı gibi olumlu yönleri olmasına karşın; kalitede önemli artış sağlamaması, ulaşım sorunu, personel eksikliği, iletişim için altyapı yetersizliği, personel memnuniyetinin düşük olması gibi olumsuzluklar bulunduğu;

- Araştırmaların önerilerine bakıldığında ise \%56 oranıyla kamu özel ortaklığı modelinin farklı alanlarda kullanılabileceği sonucuna varılmıştır.

Kamu özel ortaklığı modeli sayesinde sağlık hizmetlerine erişimin kolaylaştırılması, kısa vadede kamudaki finansal yükün azaltılması, kaliteli hizmet ile bireylerin memnuniyetinin artırılması ve yeni ve ileri teknolojik cihazlara ulaşılmasını sağlamaktadır. Bunların yanı sıra, bu yöntem ile gerçekleştirilecek yatırımların iyi planlanıp ve denetlenmesi, maliyetlerin doğru bir şekilde analiz edilip, klasik yönteme kıyasla avantajlı olup olmadığının belirlenmesi ve sonrasında pilot uygulamalar ile projelerin gerçekleştirilmesi önerilebilir. 


\section{KAYNAKÇA}

Acartürk, E. ve Keskin, S. (2012). Türkiye'de Sağlık Sektöründe Kamu Özel Ortaklığ1 Modeli. Süleyman Demirel Üniversitesi İktisadi ve İdari Bilimler Fakültesi Dergisi, 17(3), 25-51.

Alonazi, W. B. (2017). Exploring Shared Risks Through Public-Private Partnerships in Public Health Programs: A Mixed Method. BMC Public Health, 17(1), 571.

Alwani, J., Stepurko T., Anufriyeva, V., \& Shevchenko, M. (2018). Perspective of PublicPrivate Partnership in The Filed of Healthcare in Ukraine.

Asasira J. \& Ahimbisibwe F. (2019). Public-Private Partnership in Health Care and Its Impact on Health Outcomes: Evidence From Ruharo Mission Hospital in Uganda. Int'l J. Soc. Sci. Stu, . 6, 79.

Ayhan, E. ve Önder E. (2018). Türkiye'de Sağl1k Sektöründe Kamu Özel Ortaklığ1 Modeli. Uluslararası Sağlık Yönetimi Ve Stratejileri Araştırma Dergisi, 4(1), 109-21.

Baig, M. B., Panda, B., Das, J. K., \& Chauhan A. S. (2014). Is Public Private Partnership An Effective Alternative to Government in The Provision of Primary Health Care? A Case Study in Odisha. Journal of Health Management, 16(1), 41-52.

Barrows, D., Macdonald, H. I., Supapol, A. B., Dalton-Jez, O., \& Harvey-Rioux, S. (2012). Public-Private Partnerships in Canadian Health Care: A Case Study of The Brampton Civic Hospital. OECD Journal on Budgeting, 12(1), 1-14.

Baş, Ö. (2018). Să̆lık Sektöründe Kamu Özel Ortaklığı Modeli Hakkında Hizmet Sunucuları ve Hizmet Yararlanıcılarının Görüşlerinin Değerlendirilmesi: Yozgat İli Örneği. Yüksek Lisans Tezi, Atılım Üniversitesi Sosyal Bilimler Enstitüsü, Ankara.

Bilgin, N. (2006). Sosyal Bilimlerde İçerik Analizi Teknikler ve Örnek Çalışmalar. Ankara: Siyasal Kitabevi.

Bilgin, N. (2014). Sosyal Bilimlerde İçerik Analizi Teknikler ve Örnek Çalışmalar. Ankara: Siyasal Kitabevi.

Borizovska, I. B., \& Kekenovski, L. (2017). Enhancing The Macedonian Health System Through Implementation of The Public-Private Partnership Model. ILIRIA International Review, 7(1), 47-63.

Boz, S. S. (2013). Kamu Özel İşbirliği (PPP) Modeli. İnönü Üniversitesi Hukuk Fakültesi Dergisi, 4(2), 277-332.

Boztepe, M. (2018). Yeni Kamu Yönetimi Anlayışı ve Geleneksel Kamu Personel Rejimi Üzerine Etkileri. Afyon Kocatepe Üniversitesi Sosyal Bilimler Dergisi, 20(3), 191210.

Caballer-Tarazona, M., \& Vivas-Consuelo, D. (2016). A Cost And Performance Comparison of Public Private Partnership And Public Hospitals in Spain. Health Economics Review, 6(1), 17.

Chaturvedi, S., \& Randive, B. (2011). Public Private Partnerships for Emergency Obstetric Care: Lessons From Maharashtra. Indian Journal of Community Medicine, 36(1), 21-26. 
Chemtob, D., Rich, R., Harel, N., Averick, N., Schwartzberg, E., Yust, I., Maayan, S., Grotto, I., \& Gamzu, R. (2019). Ensuring HIV Care to Undocumented Migrants in Israel: A Public-Private Partnership Case Study. Israel Journal of Health Policy Research, 8(1), 80.

Commission of The European Communities. (2004). Green Paper on Public-Private Partnerships and Communty Law on Public Contracts and Concessions. https:/op.europa.eu/en/publication-detail/-/publication/94a3f02f-ab6a-47edb6b2-7de60830625e/language-en, (Erişim: 14.02.2021).

Çekirge, H. L. (2006). Dünyada Ve Türkiye'de Kamu Özel Ortaklığı Uygulamaları ve Örnek Bir Projede Modelin Finansal ve Genel Avantajlarının Değerlendirilmesi, Yüksek Lisans Tezi, İstanbul Teknik Üniversitesi Fen Bilimleri Enstitüsü, İstanbul.

Çelik F. E. (2008). Hizmet Sunumuna Katılım ve Kamu Özel Ortaklıkları, (Dosya-08: Yerel Yönetimlere Katılım, Bülten 64). Ankara: Mimarlar Odası Ankara Şubesi Yayını, 28-38.

Çınar, N. F., Türkoğlu, Ç. ve Tütünsatar, A. (2017). Kamu-Özel Ortaklığı/İşbirliği Modeli ve Sağlık Hizmetlerinin Sunumunda Hizmet Memnuniyetinin Ölçülmesi: Entegre Sağlık Kampüsleri (Şehir Hastaneleri) İçin Bir Araştırma. Journal Of Suleyman Demirel University Institute Of Social Sciences, 29(4), 215-232.

Dünya Bankası. (2017). PPP Reference Guide 3.0. https://ppp.worldbank.org/public-privatepartnership/library/ppp-reference-guide-3-0, (Erişim: 08.01.2021).

Dünya Bankası. (2021a). PPI Visualization Dashboard. https://ppi.worldbank.org/en/visualization\#sector=\&status=\&ppi=\&investment= \&region $=\& i d a=\&$ income $=\& p p p=p p p \& m d b=\& y e a r=\&$ excel=false\&map=\&header =true, $($ Erişim: 08.01.2021).

Dünya Bankası. (2021b). China. https://ppi.worldbank.org/en/snapshots/country/china, (Erişim: 11.08.2021).

Dünya Bankası. (2021c). Brazil. https://ppi.worldbank.org/en/snapshots/country/brazil, (Erişim: 11.08.2021).

Dünya Bankası. (2021d). India. https://ppi.worldbank.org/en/snapshots/country/india, (Erişim: 11.08.2021).

EPEC. (2021a). What is A Public-Private Partnership (PPP)?, https://www.eib.org/epec/find-out-more/faq.htm, (Erişim: 14.02.2021).

EPEC. (2021b). Midland Metropolitan Hospital PPP, https://www.eib.org/de/projects/pipelines/all/20140551, (Erişim: 15.02.2021).

EPEC. (2021c). Hospital De Pigo PP. https://www.eib.org/en/projects/pipelines/all/20060449, (Erişim: 16.02.2021).

Ersoy, L. (2020). Bir Kamu Hastanesi'nde Çalışan Yoğun Bakım Hemşirelerinin İş ve Yaşam Doyumları İle Ekip Çalışması Tutumları Arasındaki İlişkinin İncelenmesi. Yüksek Lisans Tezi, Kocaeli Üniversitesi Sağlık Bilimleri Enstitüsü, Kocaeli.

Fernando, D., Wijeyaratne, P., Wickremasinghe, R., Abeyasinghe, R. R., Galappaththy, G. N. L., Wickremasinghe, R., Hapugoda, M., Abeywickrema, 
W. A., \& Rodrigo, C. (2018). Use of A Public-Private Partnership in Malaria Elimination Efforts in Sri Lanka; A Case Study. BMC Health Services Research, 18(1), 202.

Gharaee, H., Tabrizi, J. S., Azami-Aghdash, S., Farahbakhsh, M., Karamouz, M., \& Nosratnejad, S. (2019). Analysis of Public-Private Partnership in Providing Primary Health Care Policy: An Experience from Iran. Journal of Primary Care $\mathcal{E}$ Community Health, 10, 1-17.

Gökkaya D. (2020). Şehir Hastaneleri Modelinin Kavramsal Çerçevesinin Değerlendirilmesi. E. Eke (Ed.), Sağlık Yönetiminde Güncel Tartışmalar İçinde (77110), Ankara: Nobel Yayınevi.

Gökkaya, D., İzgüden, D. ve Erdem, R. (2018). Şehir Hastanesinde Hasta Memnuniyeti Araştırması: Isparta İli Örneği. Süleyman Demirel Üniversitesi Vizyoner Dergisi, 9(20), 136-48.

Gupta, M. (2012). Successes and Failures of Public Private Partnership (PPP) Initiatives in Bihar. Journal of Health Studies, 22-33.

Karahanoğulları, Y. (2012). Kamu Özel Ortaklı̆̆1 Modelinin Mali Değerlendirmesi. Ankara Üniversitesi SBF Dergisi, 67(02), 95-125.

Kerman, U., Altan, Y., Aktel, M. ve Eke, E. (2012). Sağlık Hizmetlerinde Kamu Özel Ortaklığı Uygulaması. Süleyman Demirel Üniversitesi İktisadi Ve İdari Bilimler Fakültesi Dergisi,17(3), 1-23.

Khan, N. N., \& Puthussery, S. (2019). Stakeholder Perspectives on Public-Private Partnership in Health Service Delivery in Sindh Province of Pakistan: A Qualitative Study. Public Health, 170, 1-9.

Kurun, İ. (2017). Yeni Kamu İşletmeciliği Yaklaşımının Kamu Hizmetlerine Etkisi: Belediyeler Örneği. Bartın Üniversitesi İ.I..B.F. Dergisi, 8(16), 85-106.

Laar, A.K., Adler, A.J., Kotoh, A.M., Legido-Quigley, H., Lange, I.L., Perel, P., \& Lamptey, P. (2019). Health System Challenges to Hypertension and Related Non-Communicable Diseases Prevention and Treatment: Perspectives from Ghanaian Stakeholders. BMC Health Services Research, 19, 693.

McIntosh, N., Grabowski, A., Jack, B., Nkabane-Nkholongo, E. L., \& Vian, T. (2015). A Public-Private Partnership Improves Clinical Performance in A Hospital Network in Lesotho. Health Affairs, 34(6), 954-962.

Minnie, A. J. (2011). Critical Success Factors for Public-Private Partnerships in South Africa. Doktora Tezi, Stellenbosch Üniversitesi, Güney Afrika.

Nikolic, I. A., \& Maikisch, H. (2006). Public-Private Partnerships and Collaboration in The Health Sector: An Overview With Case Studies from Recent European Experience. HNP Discussion Paper.

Nuhu, S., Mpambije, C. J., \& Ngussa, K. (2020). Challenges in Health Service Delivery Under Public-Private Partnership in Tanzania: Stakeholders' Views from Dar Es Salaam Region. BMC Health Services Research, 20(1), 1-12. 
Ortega-Díaz, M.I., Ocaña-Riola, R., Pérez-Romero, C., \& Martín-Martín, J.J. (2020). Multilevel Analysis of The Relationship Between Ownership Structure and Technical Efficiency Frontier in The Spanish National Health System Hospitals. International Journal of Environmental Research and Public Health, 16(17), 1-19.

Öge, H. ve Baş, T. (2016). Türkiye'de Kamu Özel Ortaklığı Sağlık Projeleri. İşletme Bilimi Dergisi, 4(2), 105-19.

Öncü, T. S. (2018). Talan Yoluyla Sermaye Birikim Aracı Olarak Kamu-Özel Ortaklığı: Verimsiz ve Pahalı Bir Finansman Modeli. K. Pala (Ed.), Türkiye'de Sağlıkta Kamu-Özel Ortaklığı Şehir Hastaneleri İçinde (13-33), İstanbul: İletişim Yayınları.

Önder, E. (2019). Türkiye'de Kamu Özel Sektör Ortaklığı İle Yapılan Entegre Să̆lık Kampüslerinin Hasta Memnuniyeti Açısından Incelenmesi: Yozgat Şehir Hastanesi Örneği. Yüksek Lisans Tezi, Gazi Üniversitesi Sosyal Bilimler Enstitüsü, Ankara.

Özzeybek Taş, M. (2018). Vatandaşların ve Sağlık Çalışanlarının Şehir Hastaneleri İle İlgili Görüşlerinin Belirlenmesi: Ankara İli Örneği. Yüksek Lisans Tezi, Atılım Üniversitesi Sosyal Bilimler Enstitüsü, Ankara.

Ricks, E., Rooyen, D., Gantsho, M. P., \& Ham, W. (2013). Experiences of Managers and Healthcare Personnel Involved in A Functional Healthcare Public Private Partnership. Journal of Psychology in Africa, 23(2), 297-301.

Shadpour, P., Barzegar, M., \& Afzal, E. (2013). Study on The Impact of Implementing Public-Private Partnership (PPP) at Hasheminejad Kidney Center. International Journal of Hospital Research, 2(4), 195-200.

Shannon, G.D., Haghparast-Bidgoli, H., Chelagat, W., Kibachio, J., \& Skordis-Worrall, J. (2019). Innovating to Increase Access to Diabetes Care in Kenya: An Evaluation of Novo Nordisk's Base of The Pyramid Project. Global Health Action, 12(1).

Sonğur, C. ve Top M. (2018). Türkiye'de Sağlık Sektöründe Kamu-Özel İşbirliği Modeli: Paydaş Görüşlerine Dayalı Bir Alan Araştırması. SGD-Sosyal Güvenlik Dergisi, 8(1), 159-86.

Sonğur, C. (2016). Türkiye'de Kamu-Özel İşbirliği Modelinin Entegre Sağlık Kampüslerinde Uygulanmasında Paydaşların Görüş ve Değerlendirmeleri. Doktora Tezi, Hacettepe Üniversitesi Sosyal Bilimler Enstitüsü, Ankara.

Şenel Tekin, P. (2010). Türkiye'de Sağlik Sektöründe Bir Finansman Yöntemi Olarak Kamu-Özel Ortaklı̆̆ Politikasının Politika Haritalama Yöntemi İle Analiz Edilmesi. Doktora Tezi, Hacettepe Üniversitesi Sağlık Bilimleri Enstitüsü, Ankara.

Şenel Tekin, P. ve Çelik, Y. (2012). Türkiye'de Sağlik Sektöründe Bir Finansman Yöntemi Olarak Kamu-Özel Ortaklığı Politikasının Politika Haritalama Yöntemi ile Analiz Edilmesi. Ankara Să̆lık Bilimleri Dergisi, 1(3), 81-98.

Şenel Tekin, P. (2017). Küresel Kamu Özel Ortaklı̆̆ı Uygulamaları ve Türkiye Sağlık Sektörü Açısından Bir Değerlendirme. Ankara Sağlık Hizmetleri Dergisi, 16(2), 520. 
Tenşi, M. (2019). Sağlık Sektöründe Kamu-Özel Ortaklığı Modelinin Şehir Hastaneleri Ekseninde Değerlendirilmesi: İzmir Alan Çalışması. Yüksek Lisans Tezi, Muğla Sıtkı Koçman Üniversitesi Sağlık Bilimleri Enstitüsü, Muğla.

T. C. Sağlık Bakanlığı. (2019). Sağlık Bakanliğı Faaliyet Raporu 2019. https://dosyamerkez.saglik.gov.tr/eklenti/36626,tc-saglik-bakanligi-faaliyetraporu-2019pdf.pdf?0, (Erişim: 11.01.2021).

T. C. Sağlık Bakanlığı. (2021). Şehir Hastaneleri. https://sygm.saglik.gov.tr/tr,33960/sehirhastaneleri.html, (Erişim: 15.02.2021).

Thiessen, J., Bagoi, A., Homer, C., \& Rumsey, M. (2018). Qualitative Evaluation of A Public-Private Partnership for Reproductive Health Training in Papua New Guinea. Rural and Remote Health, 18, 4608.

Uğur, A. ve Miynat, M. (2014). Kamu Özel Sektör Ortaklıklarının Ekonomi Politiği. Yönetim Ve Ekonomi Dergisi, 21(2), 19-40.

Uğurluoğlu, D., Gökkaya, D. ve Erdem R. (2019). Şehir Hastanesinde Çalışan Memnuniyeti Araştırması. İktisadi İdari Ve Siyasal Araştırmalar Dergisi, 4(9), 101118.

Usta, S. ve Bilgiç, E. (2016). Yerel Yönetimlerde Hizmet Sunumu: Kamu Özel Ortaklı̆̆1 Modeli. Süleyman Demirel Üniversitesi Sosyal Bilimler Enstitüsü Dergisi, (23), 249268.

Yang, J., Song, L., Yao, X., Cheng, Q., Cheng, Z., \& Xu, K. (2020). Evaluating The Intention and Behaviour of Private Sector Participation in Healthcare Service Delivery via Public-Private Partnership: Evidence from China. Journal of Healthcare Engineering, 13.

Yereli, A.B. ve Kızıltan, M. (2011). Kamu-Özel İşbirliği Projeleri ve Kırgızistan Ekonomisi Açısından Önemi. Internatıonal Conference on Eurasian Economies, 246-252.

Yılmaz, A. (2019). Hastanelerde Veri Zarflama Analizi ve Malmquıst Endeksi Yöntemi İle Performans Ölçümü: Mersin Şehir Ĕ̆itim Araştırma Hastanesi Örneği. Yüksek Lisans Tezi, Mersin Üniversitesi Sosyal Bilimler Enstitüsü, Mersin.

1994 Tarihli ve 3996 Sayılı Bazı Yatırım ve Hizmetlerin Yap-İşlet-Devret Modeli Çerçevesinde Yaptırılması Hakkında Kanun, R.G Tarih:13/6/1994 Sayı: 21959. 
